\title{
Assessing the growth response of Vitis vinifera $L$. cv. Xynisteri, Maratheftiko, Shiraz and Sauvignon Blanc to different irrigation regimes.
}

\section{Alexander Willem Copper ( $\sim$ alexander.copper@adelaide.edu.au )}

School of Agriculture Food and Wine, Waite Research Institute, The University of Adelaide. PMB Glen Osmond, South Australia 5064, Australia.

\section{Stefanos Koundouras}

School of Agriculture, Aristotle University, 54124, Thessaloniki, Greece

Susan E. P. Bastian

School of Agriculture Food and Wine, Waite Research Institute, The University of Adelaide. PMB Glen Osmond, South Australia 5064, Australia.

\section{Trent Johnson}

School of Agriculture Food and Wine, Waite Research Institute, The University of Adelaide. PMB Glen Osmond, South Australia 5064, Australia.

\section{Cassandra Collins}

School of Agriculture Food and Wine, Waite Research Institute, The University of Adelaide. PMB Glen Osmond, South Australia 5064, Australia.

\section{Research Article}

Keywords: Xynisteri, Maratheftiko, irrigation

Posted Date: January 10th, 2022

DOI: https://doi.org/10.21203/rs.3.rs-1229873/v1

License: (c) (1) This work is licensed under a Creative Commons Attribution 4.0 International License. Read Full License 


\title{
Assessing the growth response of Vitis vinifera $L . \mathbf{c v}$. Xynisteri, Maratheftiko, Shiraz and Sauvignon Blanc to different irrigation regimes.
}

\author{
Authors: Alexander W. Copper ${ }^{1}$, Stefanos Koundouras ${ }^{2}$, Susan E. P. Bastian ${ }^{1,3}$, Trent Johnson ${ }^{1}$ and \\ Cassandra Collins ${ }^{1,3}$ \\ ${ }^{1}$ School of Agriculture Food and Wine, Waite Research Institute, The University of Adelaide. PMB \\ Glen Osmond, South Australia 5064, Australia. \\ ${ }^{2}$ School of Agriculture, Aristotle University, 54124, Thessaloniki, Greece. \\ ${ }^{3} \mathrm{ARC}$ Industrial Transformation Training Centre for Innovative Wine Production, Waite Research \\ Institute, PMB 1, Glen Osmond, SA 5064, Australia
}

\begin{abstract}
The world's changing climate is placing great pressure on the resources for sustainable viticulture. With this, it has become necessary to investigate grape varieties that are well adapted to hot climates. The aims of this study were to (1) assess the response of Xynisteri to different irrigation regimes, and (2) compare the performance of Xynisteri, Maratheftiko, Shiraz and Sauvignon Blanc grown in pots with different irrigation regimes. Trial one was established in a commercial Xynisteri vineyard in Cyprus under three different irrigation regimes - full, 50\% and no irrigation in 2019. Trial two compared three irrigation regimes - full, $50 \%$ and $25 \%$ in a potted trial of Xynisteri and Sauvignon Blanc conducted in Cyprus in 2019. Trial three was a potted trial of Xynisteri, Sauvignon Blanc, Maratheftiko and Shiraz with the same three irrigation regimes conducted in Australia in 2020/21. Vine performance and physiology measurements were taken in both trials. Fruit composition analysis, yield (field trial only), shoot, trunk and root mass measurements were performed at the end of the season. Few differences between measures were found between irrigation regimes in the field trial. Fruit composition analysis revealed fructose to be lowest in the full irrigation group compared to deficit and no irrigation treatments. The potted trial in 2019 demonstrated that for all three irrigation regimes, Xynisteri had higher stem water potential, stomatal conductance and chlorophyll content than Sauvignon Blanc. Xynisteri produced greater end of season root, shoot and leaf mass than Sauvignon Blanc under all irrigation regimes. In 2020/21, Xynisteri had greater end of season root, shoot and leaf mass than Maratheftiko and Sauvignon Blanc with Shiraz the lowest. Few significant differences in stem water potential were observed in the early stages of the trial. However, toward the end of the trial and with reduced irrigation, Xynisteri and Maratheftiko had higher stem water potential than Shiraz and Sauvignon Blanc. Xynisteri had higher stomatal conductance and chlorophyll content than Maratheftiko and both
\end{abstract}


were higher than Sauvignon Blanc and Shiraz. These results indicate that Xynisteri in particular may possess better cultivar specific growth traits than Shiraz and Sauvignon Blanc when grown under the same environmental conditions and in turn may be a more appropriate choice in areas where water is limited.

\section{Introduction}

The threat of climate change to the global wine industry is well documented. As such, many wine regions of the world are expected to face significant impacts in the next 50 years encompassing increasing temperatures, reduced rainfall, earlier harvests and heat induced berry composition changes (Jones et al., 2005, Schultz and Jones 2010, Camps and Ramos 2012, Webb 2011, Keller 2010, Webb et al., 2013, Jarvis et al., 2019, Cook and Wolkovich 2016, Krieger et al., 2011, Jones et al., 2010, Diffenbaugh et al., 2011, van Leeuwen et al., 2013 \& 2019, Hannah et al., 2013, Remenyi et al., 2019). This threat has led to many countries investigating options to adapt to these challenges, with a particular focus on the drought and heat tolerant indigenous grape varieties of hot Mediterranean climates. Recently, in Australia many producers have been seeking varieties able to cope with water limited conditions from Greece, Portugal, Spain and Georgia. However, very little research has assessed these varieties under Australian conditions and there is a lack of knowledge on how they perform.

The island of Cyprus is another hot wine growing region (Adamides 2020) with a recent upsurge in interest and research into heat and drought tolerance and a return to cultivation of their indigenous varieties (Grigoriou et al., 2020, Litskas et al., 2020, Vink et al., 2021, Heyman et al., 2021). Chrysargyris et al., (2018a) investigated the indigenous Cypriot red variety Maratheftiko by conducting a trial that compared tillage and no tillage with irrigated and non-irrigated treatments. The authors concluded that when comparing irrigation and no irrigation treatment groups in vineyards that did not undergo tillage, there was no change in yield. Also, the no tillage, no irrigation groups had an increase in berry chemistry measures; total soluble solids, total phenolics and total anthocyanins. Overall, the authors concluded that Maratheftiko is suited to cultivation in arid environments and suggested that Maratheftiko is able to tolerate arid conditions by decreasing stomatal conductance as an adaptive mechanism (Chrysargyris et al., 2018b).

In a vineyard and in a potted trial the performance of Xynisteri and Chardonnay were compared under different irrigation and tillage regimes (Chrysargyris et al., 2020; Tzortzakis et al., 2020). Xynisteri in a vineyard (clay soils) maintained yields and total soluble solid concentrations with no irrigation and low tillage levels, while in comparison, Chardonnay required irrigation and tillage to obtain high yields and adequate quality. Authors suggest that if irrigation is not available, Xynisteri is 
preferred over Chardonnay for cultivation. They also proposed that under drought conditions, a possible mechanism for Xynisteri to adapt to arid climates could include its ability to decrease stomatal conductance and photosynthetic rate along with increasing total phenols and antioxidant enzyme capacity in leaf tissue.

A similar approach has been used to evaluate indigenous Greek varieties. Koufos et al., (2020) reviewed historical data in Greece and assessed 16 indigenous Greek and 13 international varieties cultivated across 14 different regions for harvest dates, potential alcohol and titratable acidity levels. They found that indigenous Greek varieties had greater heat requirements (Growing Degree Days) compared to international varieties; and that international varieties were skewed towards earlier ripening while Greek varieties were late ripening. Average harvest dates were the $30^{\text {th }}$ of August and the $10^{\text {th }}$ of September for the international and Greek varieties, respectively. The later ripening indigenous Greek varieties experienced fewer impacts (better growth, higher stem water potential, less potential alcohol increases and acidity decreases) due to temperature increases than the international varieties and therefore potentially better adapted to future warmer climates. These studies highlight the possibility of indigenous varieties from the Eastern Mediterranean to be cultivated with reduced irrigation and be suitable for wine producers adapting to the challenges of climate change. Yet, little is known about their tolerance to reduced irrigation when compared to other more traditionally grown varieties and when grown in other environments.

Methods for scheduling irrigation times and rates can also be varied. The rate of evapotranspiration (ET) is most frequently used in vineyard/field trials to determine irrigation rates (Phogat et al., 2020). Volumetric water content is commonly used in potted trials and has been used by Tzortzakis et al., (2020) to study Maratheftiko grown in small (8 litre) containers. Nambuthiri et al., (2017) believe volumetric water content is a better method for determining irrigation rates in container grown crops than ET due to the need to determine specific crop coefficients for numerous cultivars. ET estimates also assume that the crop has access to unlimited water resources, which is often not the case in container grown crops (Incrocci et al., 2014). Girona et al., (2006) have studied the use of midday leaf water potential for scheduling deficit irrigation in vineyards and concluded that the method can increase the precision of irrigation with highly repeatable results. To date, no studies have looked at the specific irrigation rates required for optimal growth of Xynisteri and Maratheftiko and their irrigation limits remain largely unknown.

Therefore, the aims of this study were to (1) assess the response of the indigenous Cypriot variety Xynisteri to different irrigation regimes, and (2) compare the performance of Xynisteri, Maratheftiko, Shiraz and Sauvignon Blanc grown in pots with different irrigation regimes in Cyprus and Australia. 


\section{Materials and Methods}

\section{Plant material, experimental design and treatments}

The investigation involved two irrigation trials conducted in Lemesos, Cyprus during the 2019 season and one in the 2020-2021 growing season in Adelaide, Australia. Both potted trials were performed under field conditions rather than controlled environments. Trial one was established in a commercial Xynisteri vineyard, latitude $34^{\circ} 53 \mathrm{~N}$ and elevation 840 metres. The vineyard was planted at a density of 3300 vines per hectare, with 1.5 metre vine spacing by 2 metre row spacing. All vines were own rooted, with no rootstocks used. Vineyard management practices included mid row cultivation in mid-April, mid-May and mid-June. Sulphur sprays were applied three times during the growing season and pesticide sprays twice. Three different irrigation regimes were utilised: full irrigation (44 litres per vine/0.14 ML per hectare), 50\% (22 litres per vine/0.07 ML per hectare) and no irrigation. These regimes were randomly allocated to twelve vines, (four vines per treatment within a row and replicated three times) in a randomised block design, (Figure 1). Full irrigation was determined to be the usual rate at which the vineyard owner irrigated and represented the total irrigation per vine for the entire growing season. Irrigation was delivered by an in-line drip system with water meters attached to each row to measure volumes. Irrigation occurred once per week up until 2 weeks prior to the harvest date. Measurements were taken 7 days after the last irrigation episode and prior to the next. All the vines in the study were pruned to approximately 30 buds per vine. 


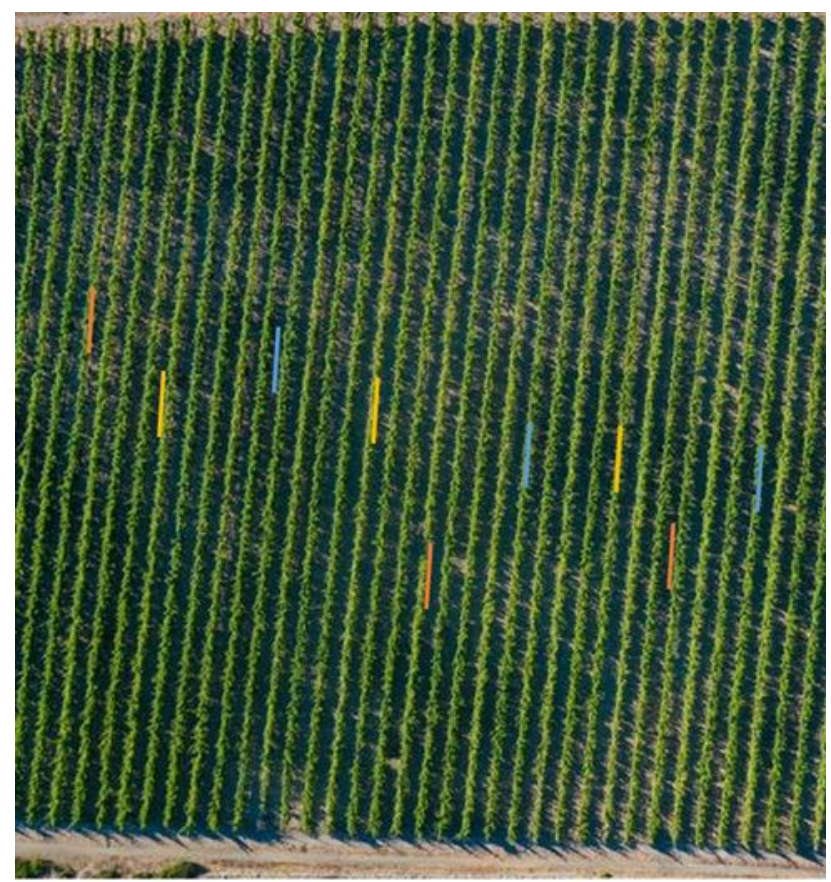

Figure 1: Randomised block design of the vineyard. Orange line- $n=4$ vines full irrigation, Yellow line$n=4$ vines deficit irrigation, Blue line $n=4$ vines no irrigation.

Trial two was a potted vine trial established from cuttings from two different Xynisteri vineyards located in two different regions in Cyprus (XK, Xynisteri Kathikas from the Kathikas region and XM, Xynisteri Mandria, from the Mandria region) and Sauvignon Blanc (SBC) sourced from a nearby vineyard. Recent work by Grigoriou et al., (2020) has identified the possibility of different clones (biotypes) within the germplasm of Xynisteri from different regions. These potential clones have yet to be identified and their characteristic differences are largely unknown at present. However, suspected different clones (biotypes) potentially exist and may have different growth properties (Koundouras pers. Comm 2019), thus determining the selection of the two Xynisteri samples used in this study.

Trial three was a potted trial set up at the University of Adelaide, South Australia of Xynisteri Paphos (XP), Sauvignon Blanc (SBA), Maratheftiko Paphos (MP) and Shiraz (SZ) with the same three irrigation regimes as the 2019 trial. XP and MP cuttings were sourced from the Cyprus Department of Agriculture vineyard research facility in the Paphos region in 2018 and transported to Australia for quarantine and testing to ensure material was free of plant pests and/or pathogens before being released in 2019 for propagation. SZ and SBA cuttings were sourced from the University of Adelaide, Waite Campus vineyard.

For both potted trials, three irrigation regimes - full irrigation (100\%), 50\% and $25 \%$ were applied to ten treatment replicates (vines) in 2019 and seven treatment replicates in 2020-2021 (due to limited 
scion material). All cuttings consisted of 4 nodes and were approximately $20 \mathrm{~cm}$ long. The basal end of the scion was coated in a rooting hormone gel, Clonex (Growth Technology Pty Ltd, O'Connor, Australia) prior to being planted in a growth medium. No rootstocks were used. The media used in both potted trials were readily available commercial potting mixes. In Cyprus, a decomposed peat and clay-based medium was used and in Adelaide a medium of decomposed bark, sand, coconut fibre and clay was used. The cuttings were then grown outside in field conditions in 55 litre pots for 18 months prior to testing to ensure root establishment; no rootstocks were used.

The full irrigation rate was determined by the Volumetric Water Content (VWC) capacity of the growing media in the pots. Water was added to the dry media in the pots until it began to exit from the drainage holes. This volume of water was recorded as the $100 \%$ VWC (Rhie and Kim 2017). Prior to the trial commencing, all pots received 8 litres three times per week, ceasing on day zero. All irrigation treatments were delivered once per week by hand using volumetric containers to ensure accurate volumes. Irrigation treatments commenced on day 7 of the trial. Full irrigation was 8 litres per vine, 50\%- 4 litres per vine and 25\%- 2 litres per vine. Pots were arranged in randomised block designs as per Figures 2 and 3.

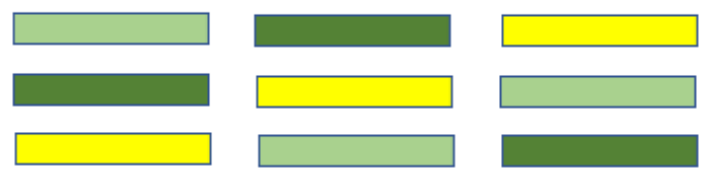

Figure 2: Randomised block design of pots in Cyprus 2019. Light Green- Xynisteri XK, Dark GreenXynisteri XM, Yellow- Sauvignon Blanc. $\mathrm{n}=10$ vines per block.

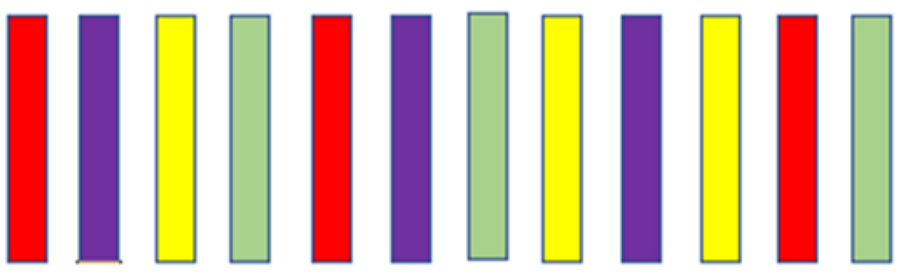

Figure 3: Randomised block design of pots in South Australia in 2020/21. Green- Xynisteri, YellowSauvignon Blanc, Red- Maratheftiko, Purple- Shiraz. $n=7$ vines per block. 


\section{Measurements}

\subsection{Climate}

A weather station (IC6250AU Davis Vantage Vue Weather Station, 4/33 The Concourse, Cowes, VIC 3922 Australia) was installed at each of the trial sites in Cyprus. General climate data for the region was supplied by the Cypriot Department of Meteorology (Republic of Cyprus Department of Meterology, 2019) and was collected from the nearest weather station at the Agriculture Research Institute in Saittas (Latitude $34^{\circ} 52^{\prime} \mathrm{N}$, Longitude $32^{\circ} 55^{\prime} \mathrm{E}$, at a distance of $16 \mathrm{~km}$ from the vineyard site). Climate data for the Adelaide potted trial was collected from a weather station (MEA Magpie Weather Stations, 1 Vine Street 5072, Magill SA, Australia) located adjacent to the testing site (Latitude $34^{\circ} 96^{\prime} \mathrm{S}$, Longitude $138^{\circ} 63^{\prime} \mathrm{E}, 0.02 \mathrm{~km}$ from the trial site).

\subsection{Vine performance measures}

Vine growth measurements at flowering (EL-21) were made, along with shoot, trunk and root mass measurements at the end of the season (EL-38) for both potted trials. Inflorescences were removed due to the age of the scion material and the limited time to produce quality fruit. Vine performance measurements, including shoot number, bunch number, bunches per shoot, shoot length, leaves per shoot, shoot diameter (at fourth internode), bunch length, bunch width and internode length (at fourth internode), were taken at flowering in the Cypriot vineyard trial to avoid any concerns associated with shoot tipping by the commercial vineyard, $n=12$ vines per treatment. All fruit from each sample vine was collected separately at harvest, bunches counted and weighed. All berries were removed from the rachis of every bunch (5-6 kg per vine, $n=12$ vines per treatment) and the fruit was homogenised in a blender.

Samples were allowed to settle overnight at $5^{\circ} \mathrm{C}$, then a $100 \mathrm{ml}$ sample of the supernatant juice underwent compositional analysis with FOSS Wine Scan FT120 (Nils Foss Allé 1, DK-3400 Hilleroed, Denmark). 


\subsection{Physiology measurements}

Data was collected for all three trials as per Table 1 . The first measurements were taken at day 0 , with irrigation treatments applied at day 7 for the potted trials and day 29 for the vineyard trial.

Table 1: Trial data collection timetable for 2019, 2020/21

\begin{tabular}{|c|c|c|c|c|}
\hline Site & Start date & End date & Total days & Measurements \\
\hline Cyprus vineyard trial 2019 & $\begin{array}{c}11^{\text {th }} \text { June } \\
\text { (EL-21) }\end{array}$ & $\begin{array}{c}26^{\text {th }} \text { September } \\
(\text { EL-38) }\end{array}$ & 107 & 5 \\
\hline Cyprus potted trial 2019 & $\begin{array}{c}19^{\text {th }} \text { July } \\
\text { (EL-33) }\end{array}$ & $\begin{array}{c}24^{\text {th }} \text { September } \\
\text { (EL-38) }\end{array}$ & 67 & 6 \\
\hline Australian potted trial 2020/21 & $\begin{array}{c}16^{\text {th }} \text { December } \\
\text { (EL-33) }\end{array}$ & $\begin{array}{c}27^{\text {th }} \text { February } \\
(\text { EL-38) }\end{array}$ & 74 & 7 \\
\hline
\end{tabular}

Potted trial testing start dates were based on 16 weeks after bud burst (EL-4) and 4 weeks after fruit set (EL-27).

A Skye SKPM1400 series Plant Moisture Vessel (Skye Instruments Ltd, Llandrindod Wells Powys, LD1 6DF, UK) was used to measure stem water potential as described by Meron et al. (1987). Midday stem water potential was measured between $12: 00$ and 14:00 on one fully expanded and undamaged leaf chosen from the mid-upper part of the canopy from every vine. Each leaf was selected from the midday sunlit side of the canopy, $n=12$ leaves per treatment were measured in the vineyard trial, $n=10$ in Cypriot potted trial and $n=7$ in Australian potted trial.

Leaves were covered with a Ziplock aluminium foil-coated plastic bag for $60 \mathrm{~min}$ before the measurement, in order to allow leaf water potential to equilibrate (Begg and Turner, 1970). After the equilibration period, the leaves were cut with a sharp blade and the stem water potential measured. A maximum of 60 seconds elapsed between cutting the leaves and recording the measurements. The same pressure chamber operator performed all the measurements with the goal of standardising the interpretation of the moment sap emerged from the petiole (Meron et al., 1987).

Leaf stomatal conductance was measured using a diffusion porometer (AP4, 2000 Delta-T Leaf Porometer Devices, Cambridge, UK). The porometer head was placed onto the required leaf and measurements were taken, which were recorded after three consecutive readings. Leaves were selected at the $4^{\text {th }}$ node along the shoot and an average of three readings was recorded for each leaf), $\mathrm{n}=12$ leaves per treatment were measured.

SPAD readings were taken as described by Marquard and Tipton (1987) using a SPAD 502 Meter 2900 (Minolta Japan), giving an approximation for chlorophyll content. Leaves were selected at the $4^{\text {th }}$ node along the shoot and an average of three readings was recorded for each leaf, $n=10$ vines were sampled in 2019 and $n=7$ vines in 2020/21. 


\subsection{Stomatal density}

Stomatal density was determined by selecting one leaf per vine from the varieties using a modified method described by Hilu and Randall (1984). Nail-polish imprints were made by applying nail-polish to the abaxial side of the leaf and allowing it to dry. Adhesive tape was placed over the area covered by nail polish and pressed down firmly. The adhesive tape was peeled from the leaf, mounted on a dry microscope slide, and viewed under a light microscope. Images were acquired on a Zeiss Axiophot Fluorescent Microscope equipped with a metric ocular 20x objective. Stomata number was counted in three different regions of each leaf and mean number per $\mathrm{mm}^{2}$ calculated. The varieties sampled were Xynisteri, Maratheftiko, Shiraz, Sauvignon Blanc and mean values for each variety determined.

\subsection{Statistical analysis}

Measurements were analysed by using the statistical package XLSTAT (version 2019.4.2, Addinsoft SARL, Paris, France). Data were reported as mean and standard error of the mean. ANOVA was used to examine the differences between irrigation treatments at each sampling date, the differences among means were identified by Tukey Honest Significance Difference (HSD) post hoc tests. Two fixed factors (time and irrigation) and one interaction factor (time*irrigation) were analysed by repeated measure ANOVA Restricted Maximum Likelihood (REML) method. P values $<0.05$ were considered significant. 


\section{Results and Discussion}

\section{Climate}

The long-term average Mean July/January Temperature (MJT) for the Krasachoria wine growing region in Cyprus is $26.1^{\circ} \mathrm{C}$ and growing season rainfall $129 \mathrm{~mm}\left(1^{\text {st }} \mathrm{April}-30^{\text {th }}\right.$ September). The longterm average MJT for Adelaide is $22.6^{\circ} \mathrm{C}$ and growing season rainfall is $140 \mathrm{~mm}\left(1^{\text {st }}\right.$ October- $31^{\text {st }}$ March).

The potted trial site in 2019 received $49 \mathrm{~mm}$ of rain during the testing period (July-September average $33 \mathrm{~mm}$ ) and the $2020 / 21$ trial site received $127 \mathrm{~mm}$ (December-February average $42 \mathrm{~mm}$ ) during the testing period. The mean daily temperature for the 2019 testing period was $24^{\circ} \mathrm{C}$ and $21^{\circ} \mathrm{C}$ in 2020/21 (Figure 4). The temperature during the 2019 trial was consistent with the long-term averages, however, the total rainfall was $370 \mathrm{~mm}$ above the long-term average with large falls recorded in January, February, March, June, August and December (Figure 4). In 2020/21 the weather was more varied compared to the long-term average data (Figure 4). The trial site experienced large variability in climate with higher maxima and lower minima than the 2019 trial and also higher rainfall. This was partly due to the La Nina phase of the El Niño-Southern Oscillation (ENSO) event experienced and is associated with a warming of the central and eastern tropical Pacific oceans that influences the climate of Eastern and Southern Australia by causing lower than average temperatures and increased rainfall (Bureau of Meteorology 2012). Typically, the Adelaide trial site experiences large climate variability, with long term records (1887-2021) indicating that January maximum temperatures can range from $17.1-46.6^{\circ} \mathrm{C}$ and minimum temperatures ranging from $8.8-33.2^{\circ} \mathrm{C}$ (Bureau of Meteorology 2021).

Liles and Verdon-Kidd (2020) investigated Growing Season Temperatures (GST) in south-east Australia and concluded that traditional growing season temperature thresholds may not be suitable for Australian wine regions. They state that a latitude adjustment is necessary to improve growing season models in Australia. While suggesting the use of a hot region classification being GST of 19$22^{\circ} \mathrm{C}$ and a very hot region being $22-24^{\circ} \mathrm{C}$. The climate of the Krasachoria wine region of Cyprus would therefore be classified as very hot and in a typical year so would Adelaide, South Australia. However, in the $2020 / 21$ season Adelaide was only classified as hot. 


\section{Vine growth and physiology measurements}

\subsection{Cyprus Xynisteri vineyard trial}

No significant differences between physiological measures and growth data at fruit set and harvest were found when comparing the three irrigation regimes in the commercial Xynisteri vineyard (Table 2 and Figure $5 a, b, c)$. While the results for stomatal conductance, chlorophyll content and in particular water potential were not significantly different between the irrigation groups, they were however similar to those reported by Copper et al., (2020). It has been demonstrated that water potential measurements respond not only to water shortage but also to other factors including cultivar, environment, soil type and the relationships between canopy and root system (GarcíaTejera et al., 2021). It is therefore possible that Xynisteri has some unique cultivar properties that enable it to maintain water potential under different water status conditions. This possibility requires further research for confirmation.

Table 2: Vine performance measures at fruit set and harvest for Xynisteri, field trial, Kato Mylos, Cyprus, 2019 growing season

\begin{tabular}{lcccccccccc}
\hline & $\begin{array}{c}\text { Shoot } \\
\text { number }\end{array}$ & $\begin{array}{c}\text { Shoot } \\
\text { length } \\
(\mathbf{c m})\end{array}$ & $\begin{array}{c}\text { Leaf } \\
\text { number }\end{array}$ & $\begin{array}{c}\text { Shoot } \\
\text { diameter } \\
(\mathbf{c m})\end{array}$ & $\begin{array}{c}\text { Internode } \\
\text { length } \\
(\mathbf{c m})\end{array}$ & $\begin{array}{c}\text { Bunch } \\
\text { length } \\
\text { flower } \\
(\mathbf{c m})\end{array}$ & $\begin{array}{c}\text { Bunch } \\
\text { width } \\
\text { flower } \\
(\mathbf{c m})\end{array}$ & $\begin{array}{c}\text { Bunch } \\
\text { number }\end{array}$ & $\begin{array}{c}\text { Average } \\
\text { bunch } \\
\text { weight } \\
\text { (gm) }\end{array}$ & $\begin{array}{c}\text { Yield } \\
\text { per } \\
\text { vine } \\
\text { (kg) }\end{array}$ \\
\hline Nil & 28.2 & 163 & 46 & 1.0 & 9.1 & 17.9 & 8.9 & 25.9 & 209 & 5.4 \\
$50 \%$ & 25.3 & 146 & 43 & 0.96 & 9.5 & 15.9 & 8.5 & 25.9 & 251 & 6.5 \\
Full & 27.3 & 141 & 42 & 0.96 & 9.5 & 17.6 & 9.4 & 24.1 & 257 & 6.2 \\
\hline $\mathrm{p}<0.05$ & $\mathrm{~ns}$ & $\mathrm{~ns}$ & $\mathrm{~ns}$ & $\mathrm{~ns}$ & $\mathrm{~ns}$ & $\mathrm{~ns}$ & $\mathrm{~ns}$ & $\mathrm{~ns}$ & $\mathrm{~ns}$ & $\mathrm{~ns}$ \\
\hline
\end{tabular}

Full- 44 litres, 50\%- 22 litres, Nil- no irrigation, ns- not statistically significant different. Shoot, bunch number, bunch length and bunch width are means of $n=12$ vines.

Must composition analysis revealed fructose to be lowest in the full irrigation group compared to deficit and non-irrigated treatments (Table 3). Fructose production is favoured in warmer conditions and can be an indication of over ripeness and higher potential alcohol (Amerine and Thoukis 1958 cited in Trad et al. 2021). The full irrigation regime may have had a role in reducing the amount of fructose produced. Similar reductions in Total Soluble Solids (TSS) with full irrigation have been demonstrated with the Cypriot variety Maratheftiko (Chrysargyris et al., 2018a) and the Greek varieties Agiorgitiko and Xinomavro (Theodorou et al., 2019). In 2019, the vineyard region received $194 \mathrm{~mm}$ of rain in the growing season (April-September). However, $106 \mathrm{~mm}$ of the rain occurred in early June and $34 \mathrm{~mm}$ occurred during two episodes in August, which may have influenced the results, especially when considering the long-term average growing season rainfall is $129 \mathrm{~mm}$. 
After 52 days of the irrigation regimes, the stem water potential for all three irrigation regimes was approximately -1.2 MPa which is regarded as moderately stressed (Girona et al., 2006). Therefore, it is difficult to conclude whether the testing period rainfall had an impact on the results or not.

Table 3: Must analysis of fruit from three irrigation regimes for Xynisteri field trial, Kato Mylos, Cyprus, 2019 growing season

\begin{tabular}{llllllllll}
\hline Treatment & $\begin{array}{l}\text { ETH } \\
(\mathbf{g} / \mathbf{l})\end{array}$ & pH & $\begin{array}{l}\text { TA } \\
(\mathrm{g} / \mathrm{l})\end{array}$ & $\begin{array}{l}\text { VA } \\
(\mathrm{g} / \mathrm{l})\end{array}$ & $\begin{array}{l}\text { Malic } \\
\text { Acid } \\
(\mathrm{g} / \mathrm{l})\end{array}$ & $\begin{array}{l}\text { Fruct } \\
(\mathrm{g} / \mathrm{l})\end{array}$ & $\begin{array}{l}\text { Gluc } \\
(\mathrm{g} / \mathrm{l})\end{array}$ & $\begin{array}{l}\text { Red } \\
\text { Sug } \\
(\mathrm{g} / \mathrm{I})\end{array}$ & $\begin{array}{l}\text { Folinc } \\
(\mathbf{m g} / \mathbf{l})\end{array}$ \\
\hline $\mathrm{Nil}$ & 0.30 & 3.90 & 1.71 & 0.31 & 1.53 & $109 \mathrm{a}$ & 114 & 206 & 104 \\
$50 \%$ & 0.25 & 3.96 & 1.66 & 0.29 & 1.57 & $109 \mathrm{a}$ & 112 & 204 & 108 \\
Full & 0.31 & 3.85 & 1.85 & 0.27 & 1.60 & $103 \mathrm{~b}$ & 107 & 194 & 103 \\
$\mathrm{Pr}>\mathrm{F}$ & $\mathrm{ns}$ & $\mathrm{ns}$ & $\mathrm{ns}$ & $\mathrm{ns}$ & $\mathrm{ns}$ & $0.04^{*}$ & $\mathrm{~ns}$ & $\mathrm{~ns}$ & $\mathrm{~ns}$ \\
\hline
\end{tabular}

FolinC (Folin-Ciocâlteu)-Gallic Acid Equivalence phenolic index. ETH-ethanol, TA-titratable acidity, VA- volatile acidity, Fruct- fructose, Gluc- glucose, RedSug- reducing sugars. Full- 44 litres, 50\%- 22 litres, Nil- no irrigation. ns- not statistically different. Each data point is a mean of $n=12$ samples. Means were separated by ANOVA using Tukey's test. * indicate significance at $p<0.05$, ns $=$ not significant. 


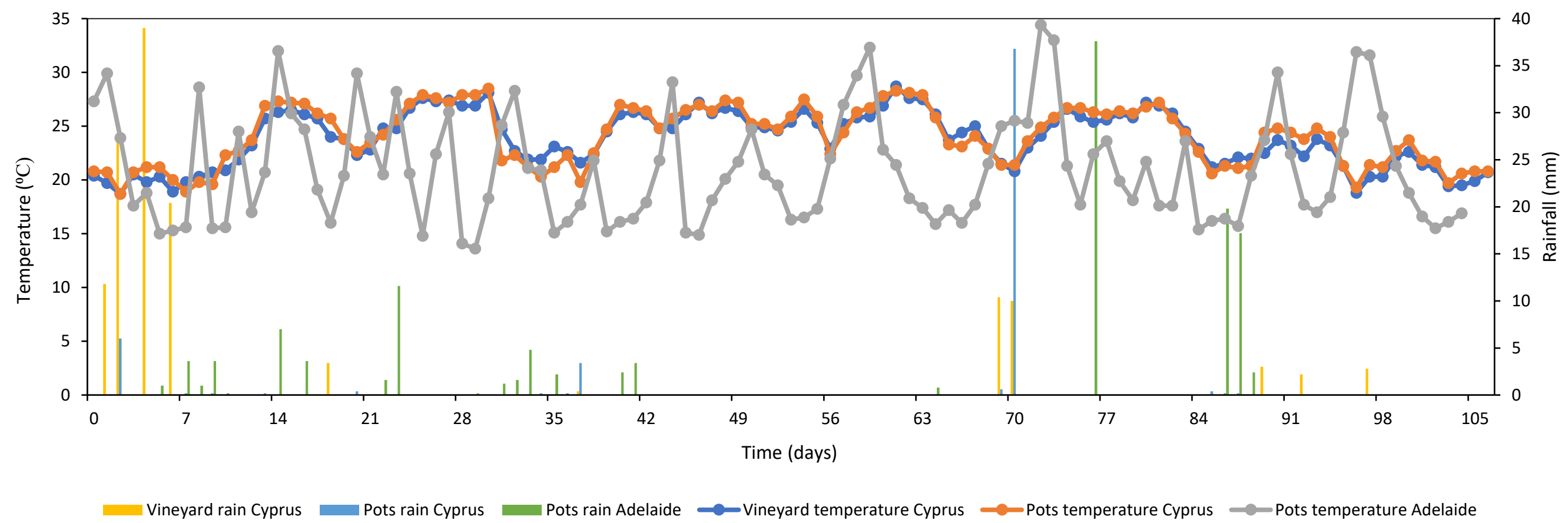

Figure 4: Climate and rainfall data for Cyprus Xynisteri vineyard site (Kato Mylos), Cyprus potted trial (Omodhos) and Adelaide Waite Campus, Australia for the testing periods 2019 and 2020/21. 


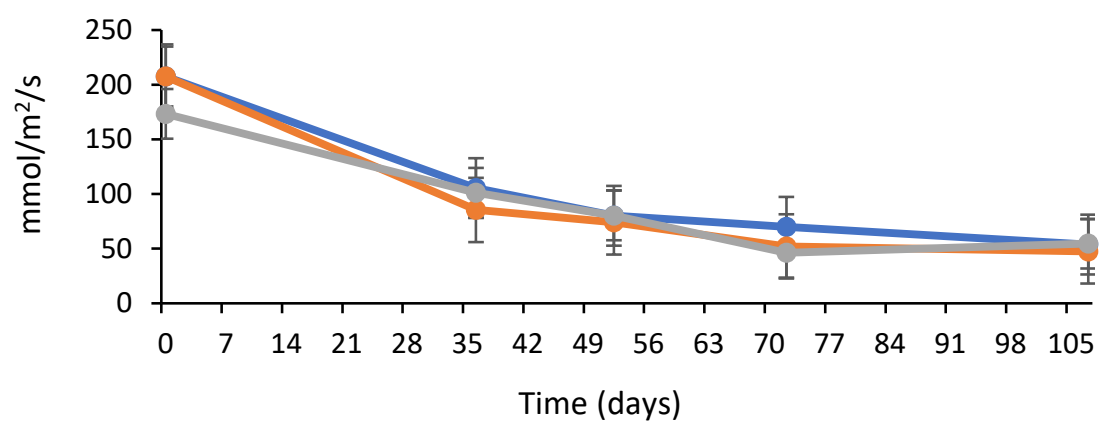

(b)

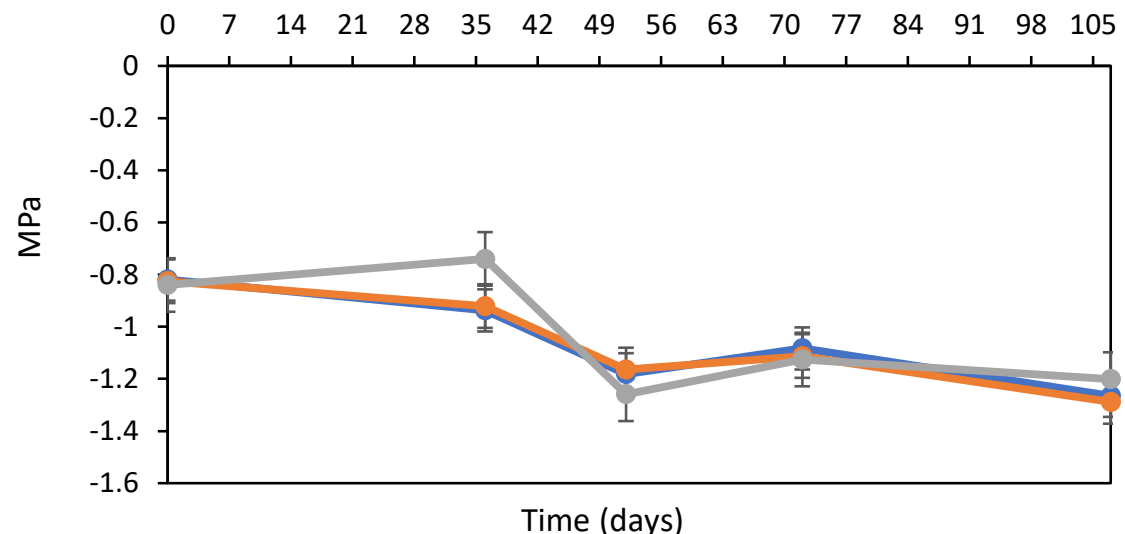

(c)

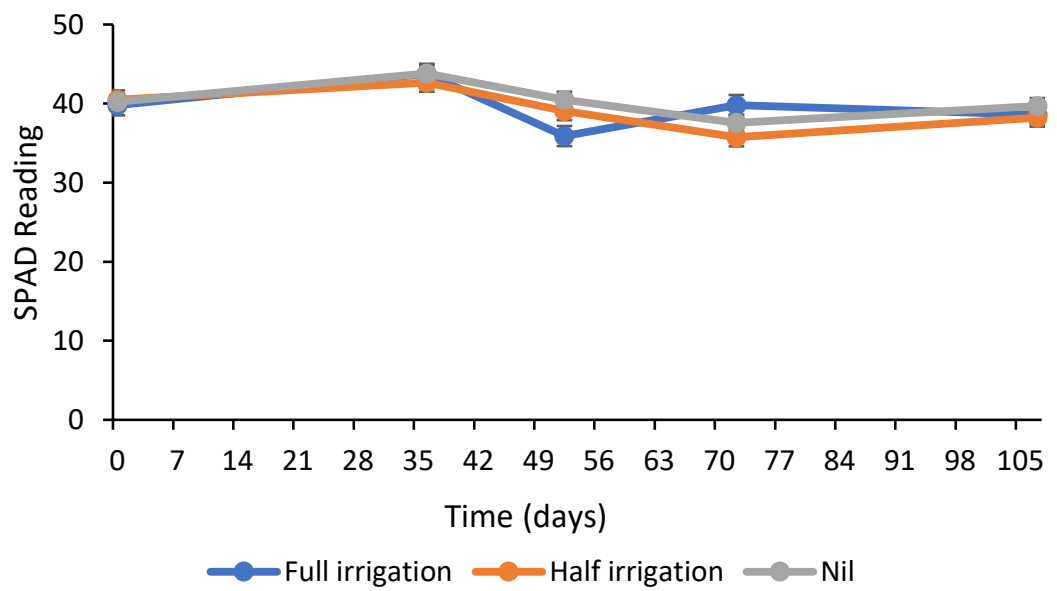

Figure 5: Vine leaf physiological measurements for 107-day test period in commercial Cypriot Xynisteri vineyard 2019. (a) stomatal conductance $\left(\mathrm{mmol} / \mathrm{m}^{2} / \mathrm{s}\right)$, (b) stem water potential (MPa), (c) SPAD reading- indicative chlorophyll content. Full irrigation- 44 litres/vine, Half irrigation- 22 litres/vine, Nil- no irrigation. Each data point is a mean of $n=12$ vines. Bars indicate the standard error. Means were separated by ANOVA using Tukey's test. 


\subsection{Potted vine trials}

In 2019, vine growth measurements were taken at flowering (Table 4). XM and XK had longer shoots and internode length than SBC as well as a greater shoot diameter. XK also had longer shoots than XM. Shoot length is important in terms of canopy capacity, Smart (1985) described vineyards that produce long shoots, large leaves and extensive lateral growth as having high vigour. This high vigour growth can have an impact on the canopy density and the exposure of fruit to sunlight and the resultant wine composition.

In 2020/21, the potted vine trial consisted of XP, MP, SBA and SZ. Growth measurements at flowering showed XP, MP and SZ had longer shoots than SBA. SZ had the most leaves per shoot and MP the least. XP and MP had the largest shoot diameter and MP had the longest internode length with SBA the shortest (Table 3). These findings are consistent with the field trial data from Copper et al., (2020) where Xynisteri had the longest shoots and the largest shoot diameter and Maratheftiko had the least leaves per shoot and longest internode length.

When comparing shoot length and internode length for $\mathrm{XM}, \mathrm{XK}, \mathrm{XP}, \mathrm{SBC}$ and $\mathrm{SBA}$ between the two seasons, we can see that in the warmer 2019 season vines had longer shoots than those from the cooler 2020/21 season. This is consistent with results seen by Galat-Giorgi et al., (2020) who noted that Malbec shoots were longer with increased temperature. Likewise with internode length and leaf number per shoot, increased temperatures are associated with shorter internode lengths and a greater number of nodes and leaves per shoot as demonstrated by Allen et al., (2017) with soybean crops. A warming climate can have significant effects on grapevines and other crops. Keller and Tarara (2010) studying Cabernet Sauvignon, report that warmer spring temperatures at bud burst can lead to large differences in shoot growth, shoot architecture and leaf development. These changes can be maintained or amplified during the growing season. They demonstrated that early season temperatures have a persistent effect on the shoot growth rate regardless of the growing season temperature. 
Table 4: Vine growth assessments at flowering for all varieties in potted trials in season 2019 and 2020/21.

\begin{tabular}{|c|c|c|c|c|}
\hline Treatment & $\begin{array}{l}\text { Shoot } \\
\text { length } \\
(\mathrm{cm})\end{array}$ & $\begin{array}{l}\text { Leaves } \\
\text { per } \\
\text { shoot }\end{array}$ & $\begin{array}{c}\text { Shoot } \\
\text { diameter } \\
(\mathrm{cm})\end{array}$ & $\begin{array}{l}\text { Internode } \\
\text { length } \\
\text { (cm) }\end{array}$ \\
\hline \multicolumn{5}{|l|}{2019} \\
\hline XM & 196 b & $87 a$ & $0.97 a$ & $7.2 \mathrm{a}$ \\
\hline XK & $2358 \mathrm{a}$ & $105 a$ & $1.03 \mathrm{a}$ & $7.5 \mathrm{a}$ \\
\hline SBC & $118 \mathrm{c}$ & $98 a$ & $0.45 b$ & $5.9 \mathrm{~b}$ \\
\hline $\operatorname{Pr}>\mathrm{F}$ & $<0.0001$ & 0.079 & $<0.0001$ & $<0.0001$ \\
\hline \multicolumn{5}{|l|}{$2020 / 21$} \\
\hline$X P$ & 152 a & $44 a b$ & $1.03 \mathrm{a}$ & $10.4 \mathrm{~b}$ \\
\hline MP & 166 a & $36 \mathrm{~b}$ & $1.09 \mathrm{a}$ & $12.6 \mathrm{a}$ \\
\hline SZ & $171 \mathrm{a}$ & $47 a$ & $0.75 \mathrm{~b}$ & $11.9 \mathrm{ab}$ \\
\hline SBA & $101 \mathrm{~b}$ & $42 a b$ & $0.74 \mathrm{~b}$ & $8.01 \mathrm{c}$ \\
\hline $\mathrm{Pr}>\mathrm{F}$ & $<0.0001$ & 0.004 & $<0.0001$ & $<0.0001$ \\
\hline
\end{tabular}

XM- Xynisteri Mandria, XK- Xynisteri Kathikas, XP- Xynisteri Paphos, MP- Maratheftiko Paphos, SBCSauvignon Blanc Cyprus, SBA-Sauvignon Blanc Adelaide, SZ- Shiraz. Different letters next to the measures indicate significant differences $(p<0.05)$, measures with the same letters are not statistically significantly different. Measures for shoot length, Shoot diameter and internode length are means of $n=10$ vines in 2019 and $n=7$ vines in 2020/21 with 2 shoots per vine.

In 2019, under full irrigation XM and XK had higher stem water potential than SBC on day 38 only (Figure 6a), with XM and SBC at moderate levels of stress (between -1.1 and -1.2 MPa). Under 50\% irrigation, on day 7 SBC had higher stem water potential than XM and XK. XM and XK were higher than SBC at days 38 and 52. Additionally, at day 52 XK was higher than XM (Figure 6b). XM and XK were under moderate stress levels at day 19, followed by SBC at day 38. Under $25 \%$ irrigation, at day 7 SBC had higher stem water potential than XK and XM. XM and XK had higher stem water potential than SBC at days 38, 52 and 67 (Figure 6c). All varieties were under moderate stress by day 7 with SBC under severe stress (-1.5 MPa) by day 38. Repeated ANOVA indicated that stem water potential was significantly affected by time, irrigation rate and their interactions (Table 5), that is, stem water potential decreased significantly with time and for all irrigation levels, with the largest decrease occurring for SBA under $25 \%$ irrigation.

In 2020/21 under full irrigation MP, XP and SZ stem water potentials were all higher than SBA on day 73 only (Figure $6 \mathrm{~d}$ ), with all except for MP under moderate stress.

At day 35 SZ had the highest stem water potential, followed by MP, SBA, and XP the lowest. Under $50 \%$ irrigation, on day $39 \mathrm{MP}$ and SZ stem water potentials were highest followed by SBA and XP. On day 73 XP had the highest stem water potential followed by SZ, MP and SBA (Figure 6e). 
XP was under moderate stress from day 35 onwards, SBA from day 39 onwards and MP and SZ from day 64 onwards.

Under $25 \%$ irrigation SBA stem water potential was highest on day 7 followed by SZ, MP with XP the lowest. On day 35 SZ was the highest followed by SBA, XP and MP the lowest (Figure 6f). All varieties were under moderate stress by day 21 with all under severe stress (-1.5 $\mathrm{MPa}$ ) by day 73 . Repeated ANOVA indicated that stem water potential was significantly affected by time, irrigation rate and their interactions (Table 5). Under full and 50\% irrigation SBA stem water potential decreased the most at the end of the trial, while under $25 \%$ irrigation XP and XM stem water potentials decreased earlier and mid-way through the trial when compared with SZ and SBA.

While the results for 2020/21 were not conclusive, findings for 2019 were similar to those reported by Copper et al., (2020) who demonstrated that Xynisteri had higher stem water potential than Maratheftiko and Shiraz, while Sauvignon Blanc had the lowest stem water potential. Water potential has been widely used as an indicator of plant water status for irrigation management purposes (García-Tejera et al., 2021). There is however some conjecture about the levels of stem water potential that are considered as moderate and severely stressed. Alatzas et al., (2021) consider values lower than -1.1 MPa as severe stress and Girona et al., (2006) consider -1.2 MPa moderate stress and -1.5 MPa severe stress. This could also be cultivar dependant, with modifications of the ratio of root to leaf area inducing changes in the relationship between water potential, transpiration and soil water content (Bauerle et al., 2008). For example, Bauerle et al., (2008) studied high and low vigour rootstocks and concluded that some high vigour rootstocks may be more plastic and have evolved to grow roots in the deeper, moister soil regions later in the growing season. This could help to explain the root mass results seen, particularly for Xynisteri in 2020/21. The cultivar and root structure differences for Xynisteri and Maratheftiko may be the reason why the water potential decreases were not significant until the end of the testing period after 74 days of water stress. That is, they have evolved to develop deeper roots later in the growing season, when soil water content has decreased. Future longitudinal studies of root development of Maratheftiko and in particular Xynisteri compared to other varieties over the growing period could confirm this. 
(a)

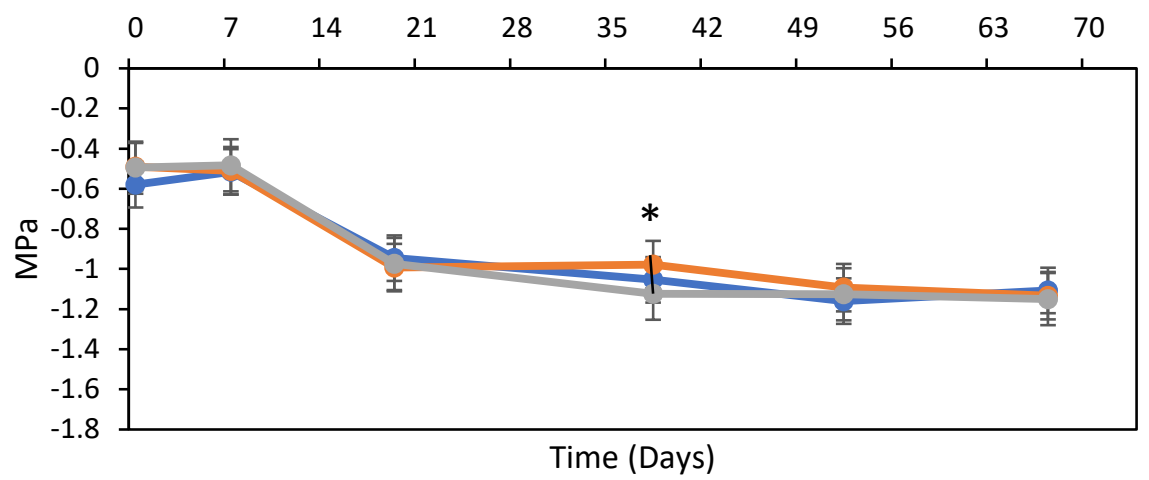

(b)

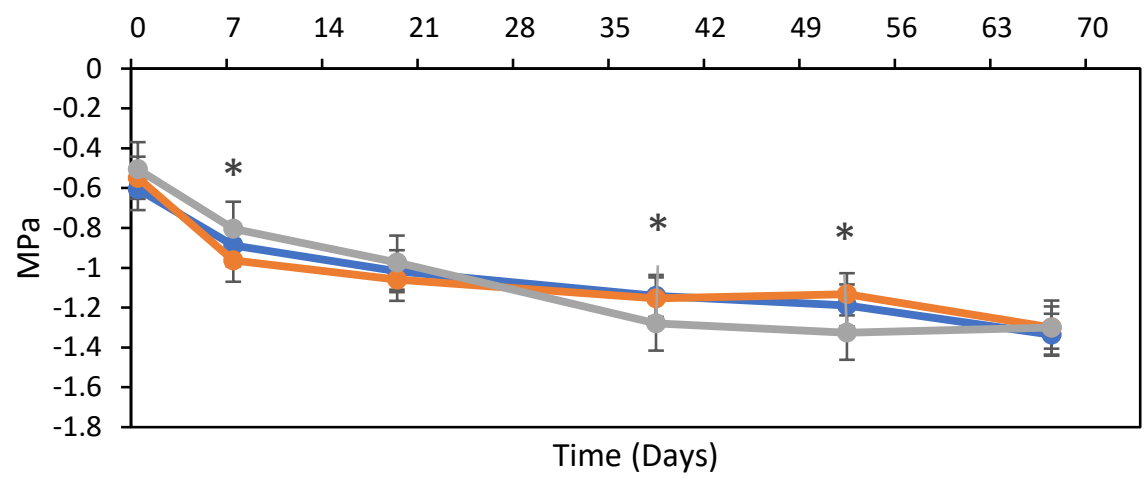

(c)

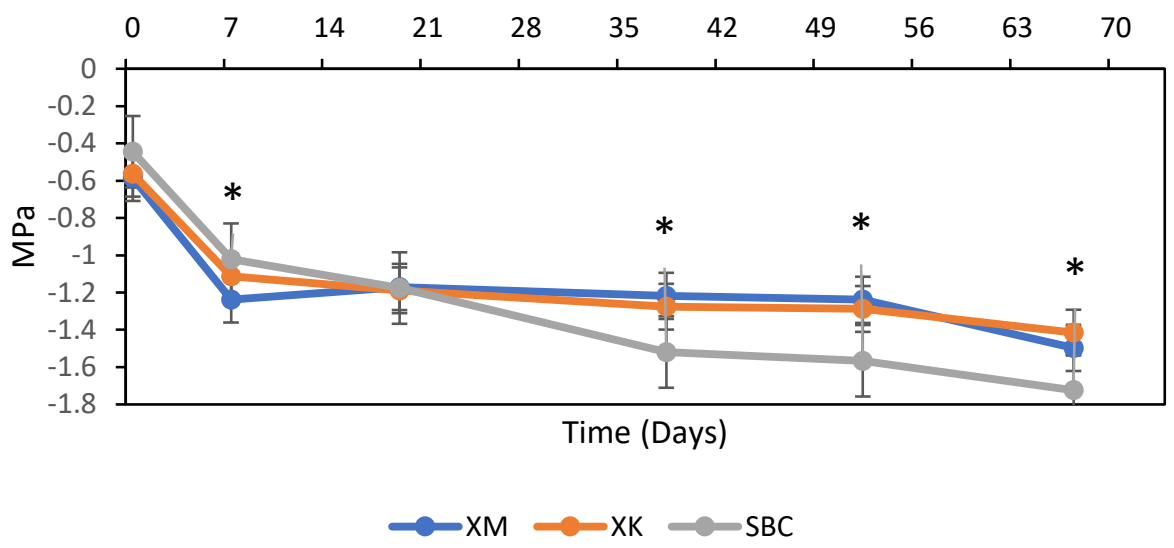




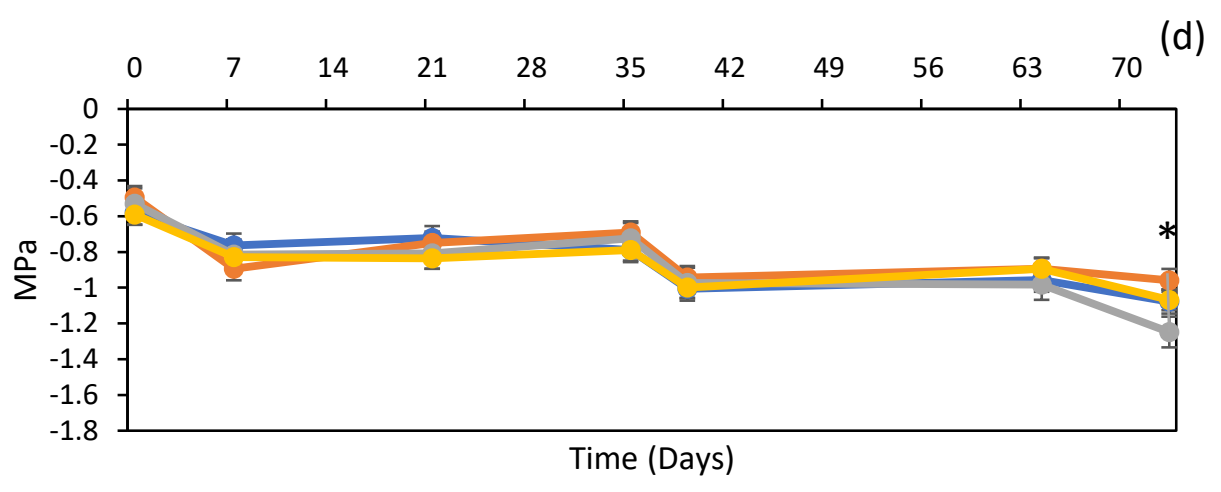

(e)

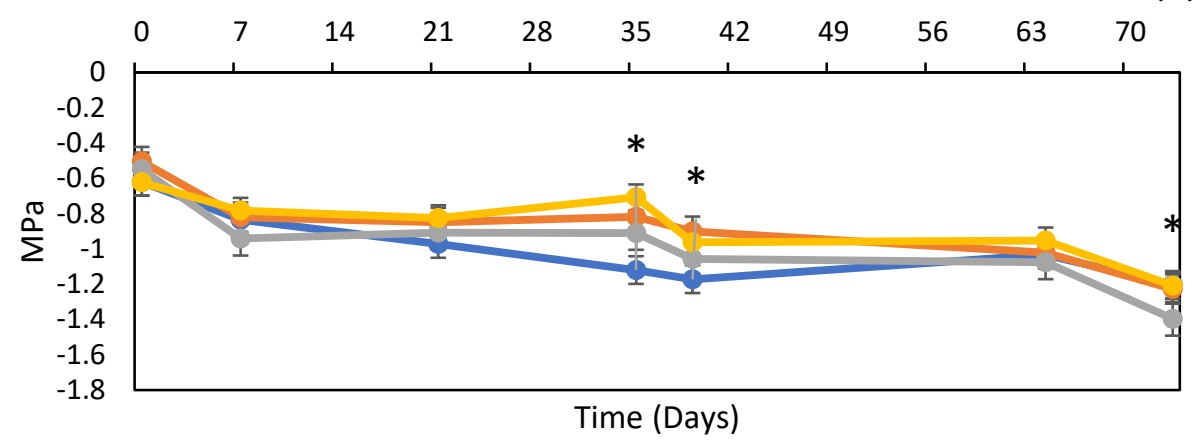

(f)

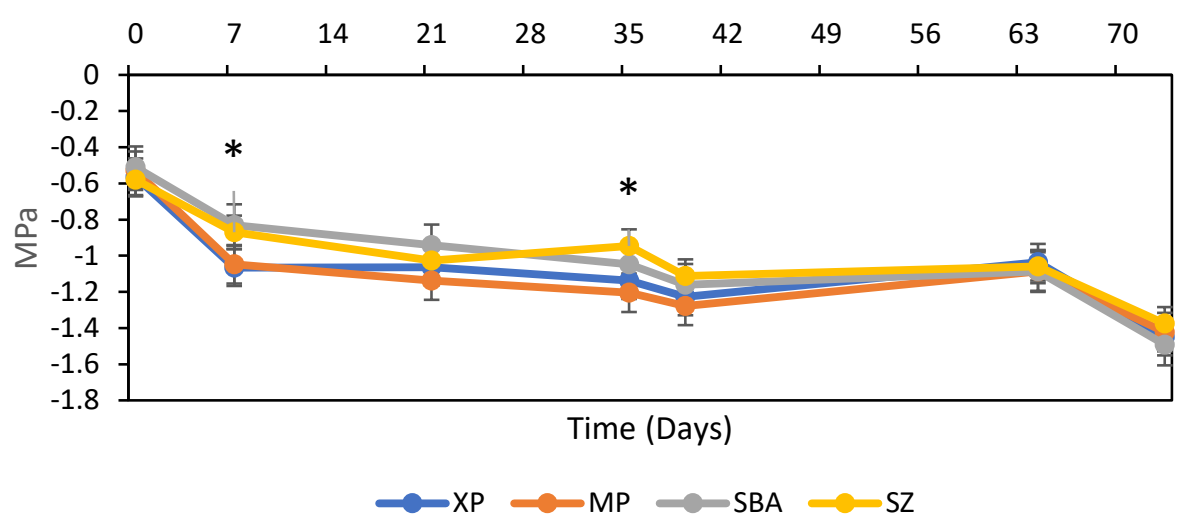

Figure 6: Stem water potential ( $\mathrm{MPa}$ ) measures for potted trials for seasons 2019 and 2020/21.

XM- Xynisteri Mandria, XK- Xynisteri Kathikas, XP- Xynisteri Paphos, MP- Maratheftiko Paphos, SBCSauvignon Blanc Cyprus, SBA- Sauvignon Blanc Adelaide, SZ- Shiraz.

(a) Full irrigation 2019, (b) 50\% irrigation 2019, (c) 25\% irrigation 2019, (d) Full irrigation 2020/21, (e) $50 \%$ irrigation 2020/21, (f) 25\% irrigation 2020/21. Each data point are means of $n=10$ vines in 2019 and $n=7$ vines in 2020/21. Bars indicate the standard error. Means were separated by ANOVA using Tukey's test. * indicate significance at $p<0.05$. 
Table 5: Repeated measures ANOVA applied to stem water potential, stomatal conductance and SPAD reading in relation to time, irrigation (treatment) and their interactions.

\begin{tabular}{|c|c|c|}
\hline Factor & F value & $p$-value \\
\hline \multicolumn{3}{|l|}{2019} \\
\hline \multicolumn{3}{|c|}{ Stem water potential } \\
\hline Time & 104.376 & $<0.0001^{*}$ \\
\hline Irrigation & 51.823 & $0.0002 *$ \\
\hline Time*Irrigation & 4.484 & $0.001 *$ \\
\hline \multicolumn{3}{|c|}{ Stomatal conductance } \\
\hline Time & 118.548 & $<0.0001^{*}$ \\
\hline Irrigation & 27.634 & $0.001^{*}$ \\
\hline Time*Irrigation & 5.131 & $0.0002^{*}$ \\
\hline \multicolumn{3}{|l|}{ SPAD reading } \\
\hline Time & 1.286 & 0.296 \\
\hline Irrigation & 0.234 & 0.799 \\
\hline Time*Irrigation & 1.976 & 0.073 \\
\hline \multicolumn{3}{|c|}{$2020 / 21$} \\
\hline \multicolumn{3}{|c|}{ Stem water potential } \\
\hline Time & 119.446 & $<0.0001^{*}$ \\
\hline Irrigation & 15.992 & $0.001^{*}$ \\
\hline Time*Irrigation & 3.731 & $0.0004^{*}$ \\
\hline \multicolumn{3}{|c|}{ Stomatal conductance } \\
\hline Time & 90.098 & $<0.0001^{*}$ \\
\hline Irrigation & 2.065 & 0.183 \\
\hline Time*Irrigation & 1.367 & 0.210 \\
\hline \multicolumn{3}{|l|}{ SPAD reading } \\
\hline Time & 16.054 & $<0.0001^{*}$ \\
\hline Irrigation & 0.133 & 0.877 \\
\hline Time*Irrigation & 0.127 & 1.000 \\
\hline
\end{tabular}

* indicate significance at $p<0.05$

In 2019 under full irrigation, XM and XK had higher stomatal conductance than SBC on day 38 (Figure 7a), XM was also higher than XK. Cifre et al., (2005) consider $50-150 \mathrm{mmol} / \mathrm{m}^{2} / \mathrm{s}$ the threshold for severe water stress, using this classification XK and SBC were stressed from day 39 and XM from day 38.

Under 50\% irrigation XM and XK had higher stomatal conductance than SBC at days 19, 38 and XK was higher than XM (Figure 7b). All varieties were classed as stressed after day 7.

Under 25\% irrigation XM and XK were higher at days 0, 19, 38, 52 and 67 than SBC. Additionally, at day 19 XM was higher that XK and at day 52 XK was higher than XM (Figure 7c). All varieties were classed as stressed after day 7.

Repeated measures ANOVA indicated that stomatal conductance was significantly affected by time, irrigation rate and their interactions (Table 5), that is, there was a decrease in stomatal conductance for all three varieties, with the largest decrease occurring for SBC under 25\% irrigation rates. 
In 2020/21 under full irrigation stomatal conductance for XP was the highest on every occasion. SZ was the lowest on days 0 and 7, while SBA had the lowest stomatal conductance on days $21,35,39$, 64 and 73 (Figure 7d). SZ was considered stressed at day 7, SBA at day 35, XP and MP never fell below $150 \mathrm{mmol} / \mathrm{m}^{2} / \mathrm{s}$ for the entire testing period.

Under 50\% irrigation XP was the highest on days $0,7,21,64$ and 73, While MP was the highest on days 35 and 39. The lowest stomatal conductance was SZ on days $0,7,21$ and 35 with SBA the lowest on days 39, 64 and 73 (Figure 7e). SZ was considered stressed at day 7, SBA at day 21, XP at day 35 and MP at day 39.

Under 25\% irrigation XP had the highest stomatal conductance on days $0,7,21,64$ and 73 . SZ had the lowest on days 0, 7 and 21 while SBA was the lowest on days 64 and 73 (Figure 7f). SZ was considered stressed at day 7, SBA at day 21, MP at day 21 and XP at day 35. Repeated ANOVA indicated that stomatal conductance was significantly affected by time only (Table 5), that is, it decreased over time at a much greater rate for SBA and SZ than for MP and XP. 
(a)

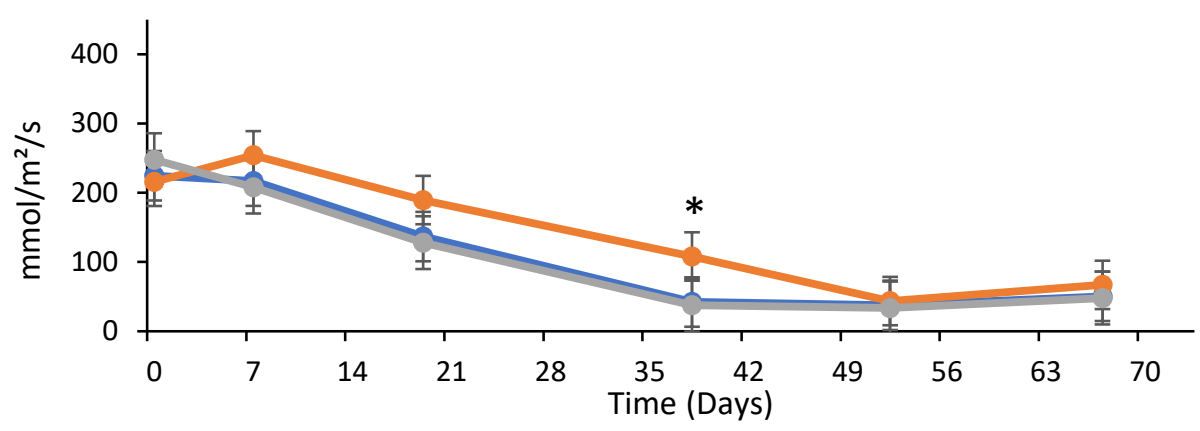

(b)

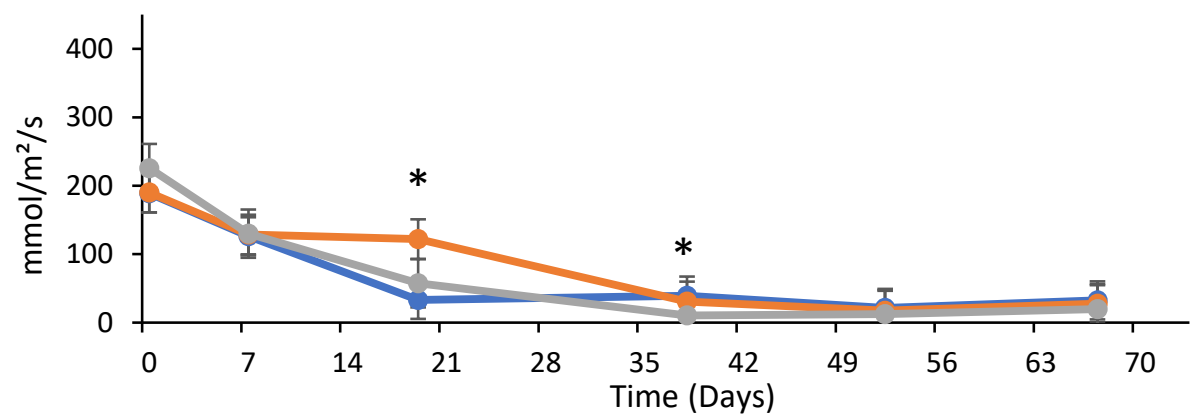

(c)

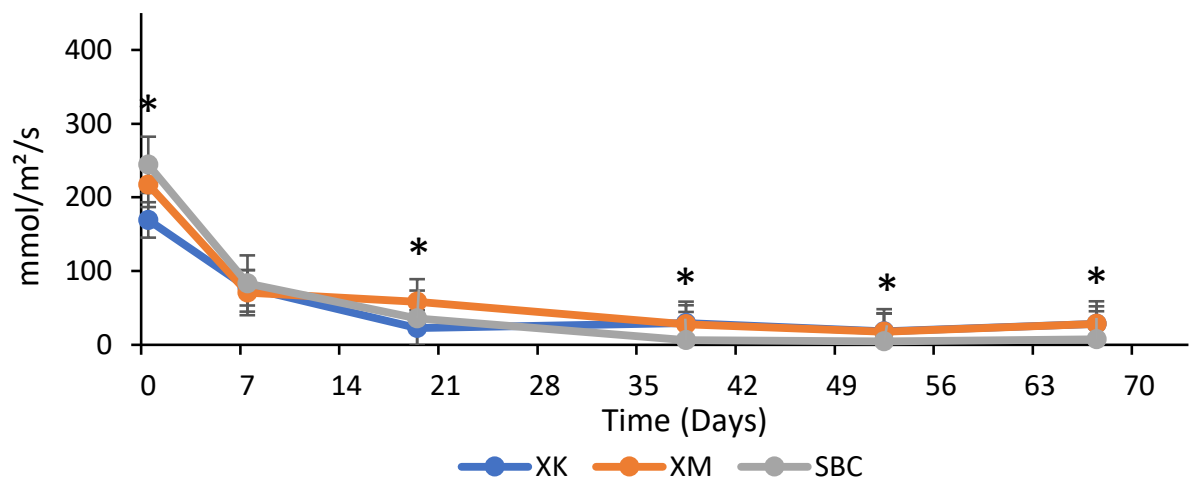


(d)

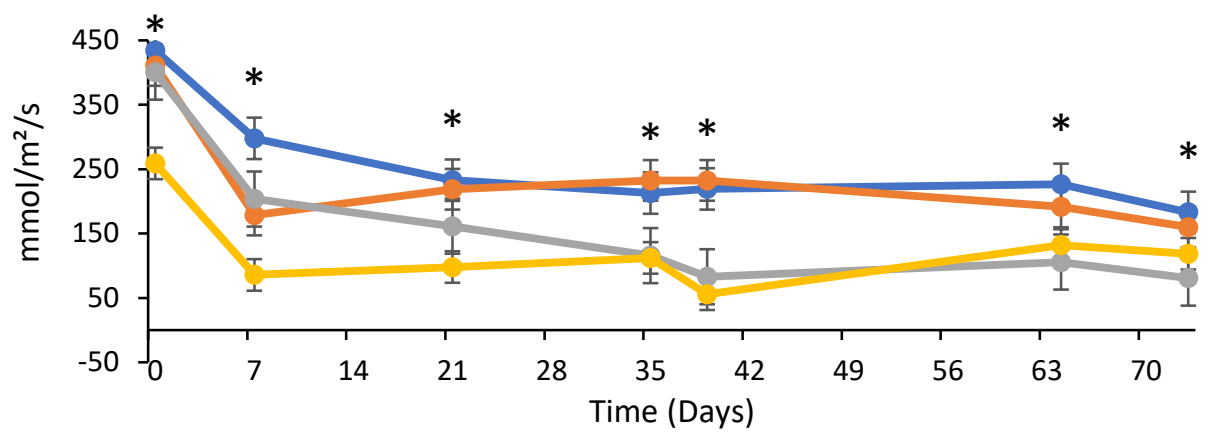

(e)

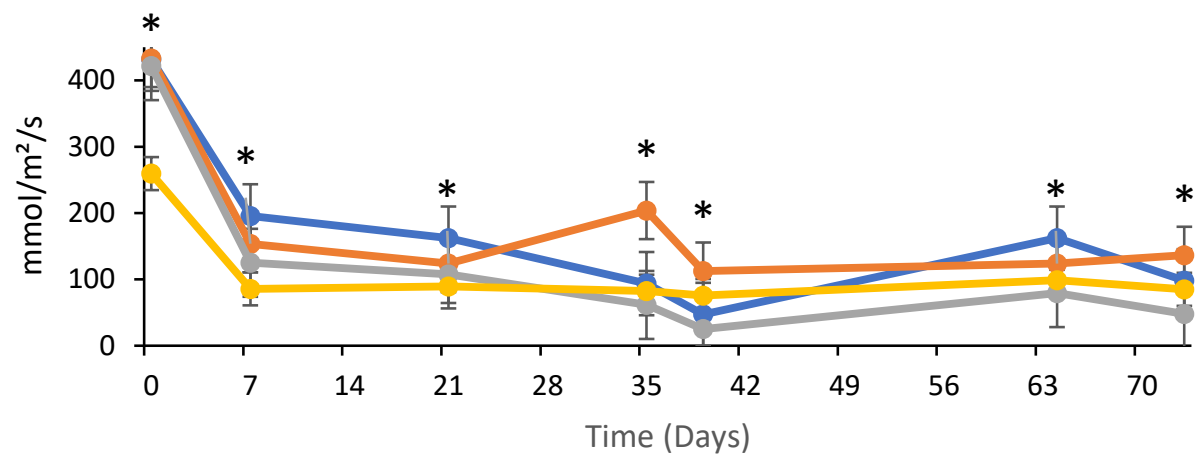

(f)

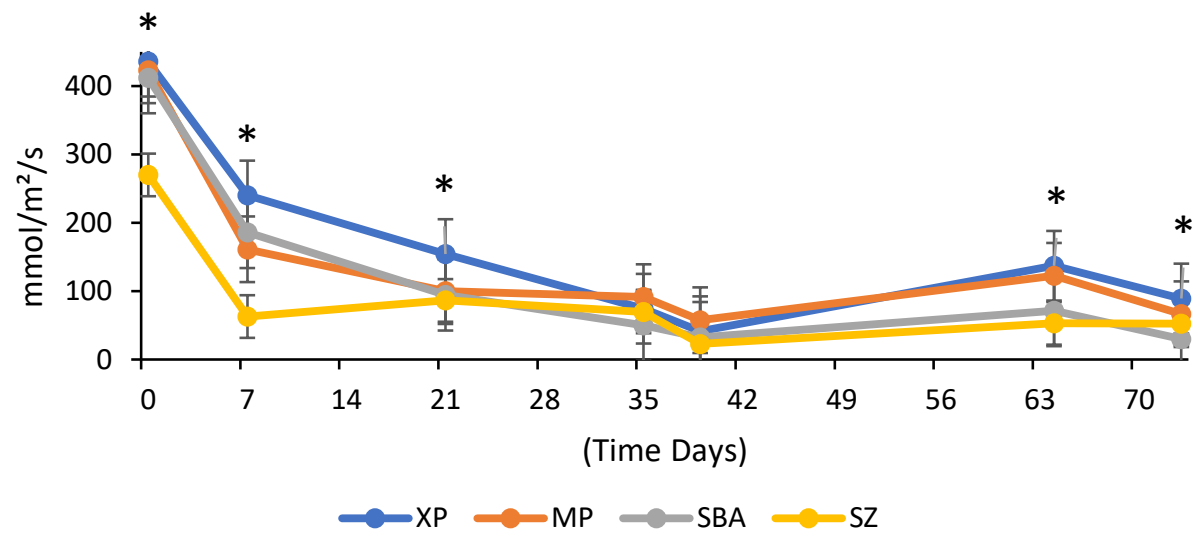

Figure 7: Stomatal Conductance $\left(\mathrm{mmol} / \mathrm{m}^{2} / \mathrm{s}\right)$ measures for potted trial for seasons 2019 and 2020/21.

XM- Xynisteri Mandria, XK- Xynisteri Kathikas, XP- Xynisteri Paphos, MP- Maratheftiko Paphos, SBCSauvignon Blanc Cyprus, SBA- Sauvignon Blanc Adelaide, SZ- Shiraz.

(a) Full irrigation 2019, (b) 50\% irrigation 2019, (c) 25\% irrigation 2019, (d) Full irrigation 2020/21, (e) $50 \%$ irrigation 2020/21, (f) 25\% irrigation 2020/21. Each data point are means of $n=10$ vines in 2019 and $n=7$ vines in 2020/21. Bars indicate the standard error. Means were separated by ANOVA using Tukey's test. * indicate significance at $p<0.05$. 
From this data we can see that XP had higher stomatal conductance and SZ had the lowest in the early stages of testing, with SBA being the lowest in the later developmental stages. This is similar to the results seen by Copper et al., (2020) who found that Xynisteri and Maratheftiko had greater stomatal conductance than Shiraz and Sauvignon Blanc in a vineyard trial. All the varieties in this study showed a reduction in stomatal conductance over time but at differing rates. Tzortzakis et al., (2020) studying Xynisteri and Chardonnay showed similar results for Xynisteri but saw that stomatal conductance for Chardonnay was relatively constant throughout their testing period. They concluded that this was a possible mechanism in which Xynisteri responds to drought stress by improved stomata conductance regulation.

The literature, however, is not so clear and in recent times, stomatal regulation has been a topic of much research and conjecture. The classification for drought tolerance in grapevines often utilises the binary terms isohydric and anisohydric (Gerzon et al., 2015). Isohydric vines are said to be able to maintain constant low water potentials through rapid stomatal closure, while anisohydric vines only close stomata at very low water potentials. Chaves et al., (2010) state that the distinction between isohydric and anisohydric plants is not clear, and that they may be able to switch between strategies depending on drought severity and environmental conditions.

Levin et al., (2020) however, reject the premise of isohydric and anisohydric behaviour entirely. They studied 17 different cultivars in a field experiment under three irrigation regimes. They measured pre-dawn and midday leaf water potential as well as midday stomatal conductance. They concluded that stomatal behaviour is an across-cultivar continuum and call into question the isohydric and anisohydric classification system. They state that in general, cultivars respond similarly to one another at high and low water status, but stomatal behaviour differs at moderate water status. They believe that $V$. vinifera cultivars possess both isohydric and anisohydric stomatal behaviour that is dependent on the intensity of water deficits. Hochberg et al., (2018) agree and state that the use of the iso/anisohydric terminology should be abandoned for two reasons: (i) the different definitions are not necessarily in agreement with one another, creating confusion as to the actual meaning of the terms; and (ii) the environmental effects are at least as significant as the genotypic effect, and thus a cultivar's hydraulic behaviour cannot be predicted without accounting for the environment (Hochberg et al., 2018 and Villalobos-González et al., 2019, Dayer et al., 2020). This may be the reason for the results that were seen in this study. That is, all varieties had a decrease in stomatal conductance over the testing period, with SBC, SBA and SZ showing the largest decreases with all irrigation regimes. 
SPAD readings in both seasons ranged between 15 and 40 , which is consistent with results seen by Steele et al., (2008) who state that SPAD readings are adequately sensitive at around 35 (chlorophyll content approximately $300 \mathrm{mg} / \mathrm{m}^{2}$ ). Their research demonstrated that grapevine leaves can have SPAD values of between 7 and 44 which equates to a chlorophyll content of between 63 to $576 \mathrm{mg} / \mathrm{mm}^{2}$. Ling et al., (2011) report that SPAD readings are proportional to the amount of chlorophyll present in the leaf and that converted SPAD values differ from photometric measurements of solvent-extracted chlorophyll by just $6 \%$, as well as being a non-destructive method suitable for preserving the leaves of plants being studied.

Both XM and XK had higher SPAD readings/chlorophyll content when compared to SBC throughout the testing period in 2019. Chlorophyll content for all three varieties remained constant throughout the testing period (Figure 8a, b, c). Repeated ANOVA indicated that there were no interactions for time and irrigation rates in SPAD readings (Table 5).

In 2020/21 SPAD readings/chlorophyll content for XP and MP were the highest for all three irrigation regimes at every testing period. Conversely SBA and SZ were the lowest for all three irrigation regimes and testing period. Overall, all the four varieties increased their chlorophyll content over the testing period, XP and MP in particular increased their chlorophyll content with $50 \%$ and $25 \%$ irrigation (Figure 8d, e, f). Repeated ANOVA indicated that SPAD readings were significantly affected by time only (Table 5), that is XP and MP had higher chlorophyll content than SZ and SBA under all irrigation regimes over the course of the trial This again concurs with results seen by Copper et al., (2020) where Xynisteri and Maratheftiko had higher chlorophyll content than Shiraz and Sauvignon Blanc. They however identified that in a vineyard, Maratheftiko had higher chlorophyll content than Xynisteri, which was not the case with the potted trials.

Chrysargyris et al., (2020) compared Xynisteri with Chardonnay in a vineyard and found that the level of chlorophyll amongst irrigation and no irrigation groups varied. In irrigated vines, chlorophyll decreased at flowering and increased at veraison with no irrigation. Xynisteri chlorophyll levels were unchanged between treatment groups at flowering, veraison and harvest, but overall levels showed a decreasing trend throughout the testing period. Tzortzakis et al., (2020) studying Xynisteri and Chardonnay in pots showed Chardonnay chlorophyll content levels decreased after eight days of drought stress and Xynisteri showed similar affects after 20 days. With heat stress conditions, both Xynisteri and Chardonnay showed reduced levels after 20 days.

Chrysargyris et al., (2018a) studying Maratheftiko in a vineyard trial with varying irrigation found that chlorophyll content was constant throughout the testing period for all irrigation groups except for the irrigated group at harvest, where a decrease in chlorophyll content was seen. Similar results 
were demonstrated by Chrysargyris et al., (2018b) studying Maratheftiko in pots under heat and drought stress conditions. Chlorophyll content was maintained after 20 days of light drought stress compared to full irrigation. However, moderate drought stress caused a decrease. Heat stress caused a decrease in chlorophyll content after 20 days, but overall drought stress had a larger impact than heat stress. These results indicate that both Xynisteri and Maratheftiko overall are able to maintain or in some cases increase their chlorophyll content across a growing season and are able to do this more efficiently than Chardonnay, Sauvignon Blanc and Shiraz. Liu et al., (2019) investigating chlorophyll content as a predictor of above ground biomass in rice crops, demonstrated that higher chlorophyll content in leaves correlated with an increase in above ground biomass. This may be the reason XM, XK, XP and MP developed higher biomass than SBC, SBA and SZ.

Chlorophyll content and the nitrogen status of Shiraz grapevines (measured by SPAD) was studied by Metya et al., (2014) grown in pots. They concluded that nitrogen supply altered the whole plant biomass and its distribution between annual and perennial parts of the plants. Nitrogen deficiency slows growth and causes a higher biomass allocation to perennial parts of the plant (particularly the trunk), this however is cultivar dependant, Merlot grown under reduced nitrogen levels demonstrated enhanced root growth at the expense of aboveground growth. This adds to the paradox of the Xynisteri results, with it demonstrating high chlorophyll content (leaf nitrogen), large above ground biomass and large root biomass. 
(a)

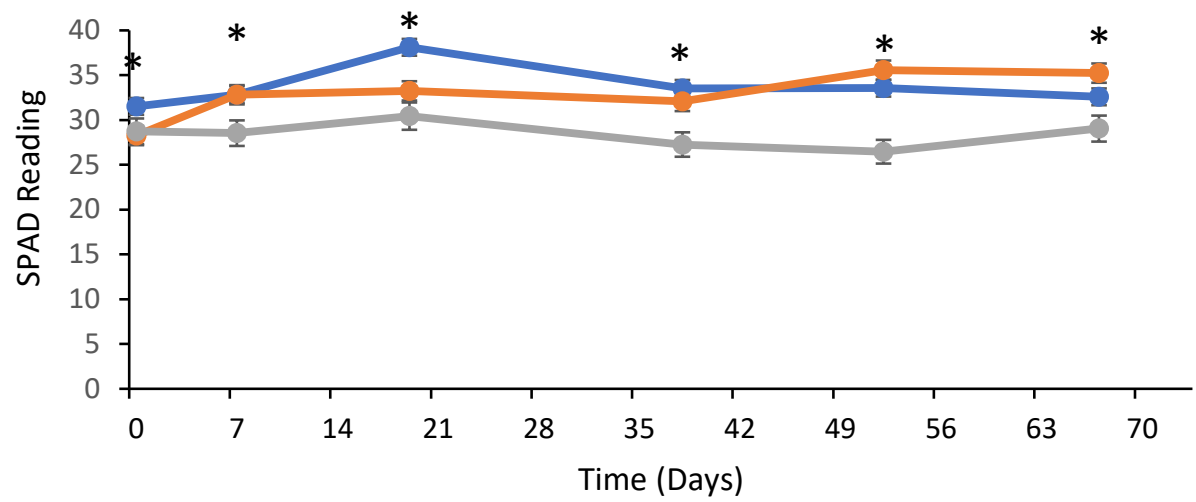

(b)

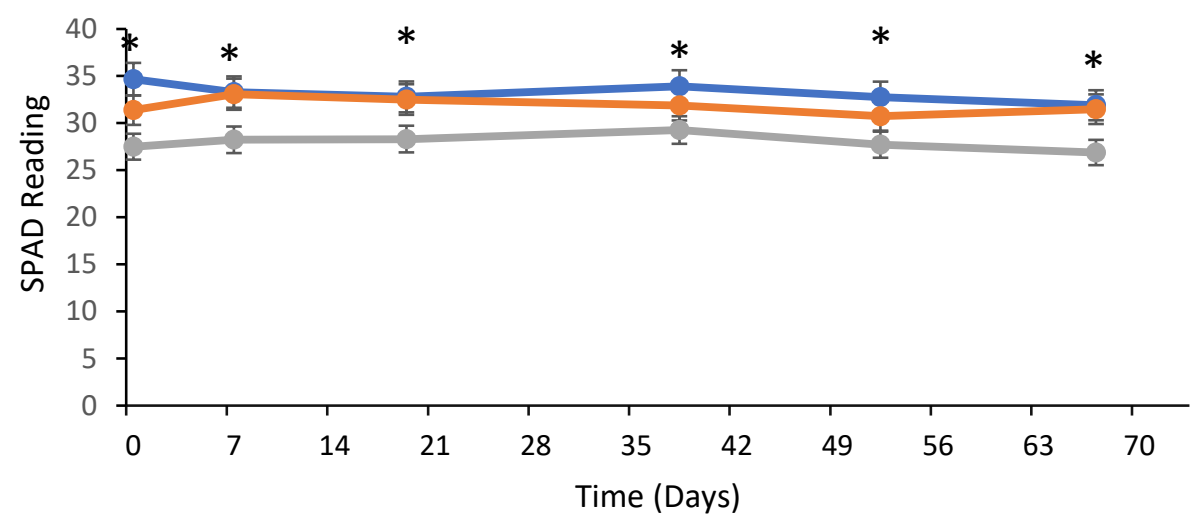

(c)

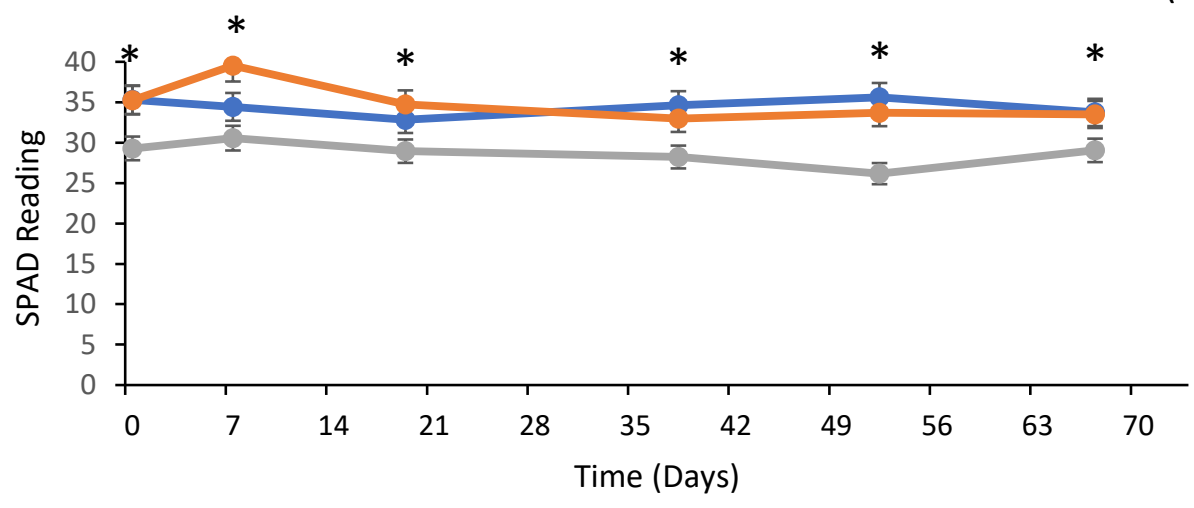

$\longrightarrow \mathrm{XK} \longrightarrow \mathrm{XM} \longrightarrow \mathrm{SBC}$ 
(d)

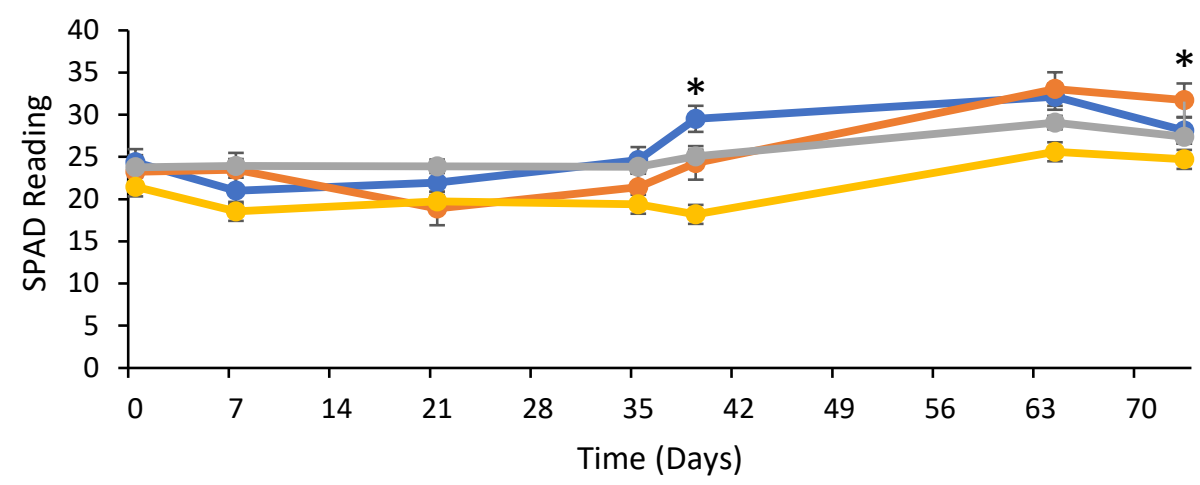

(e)

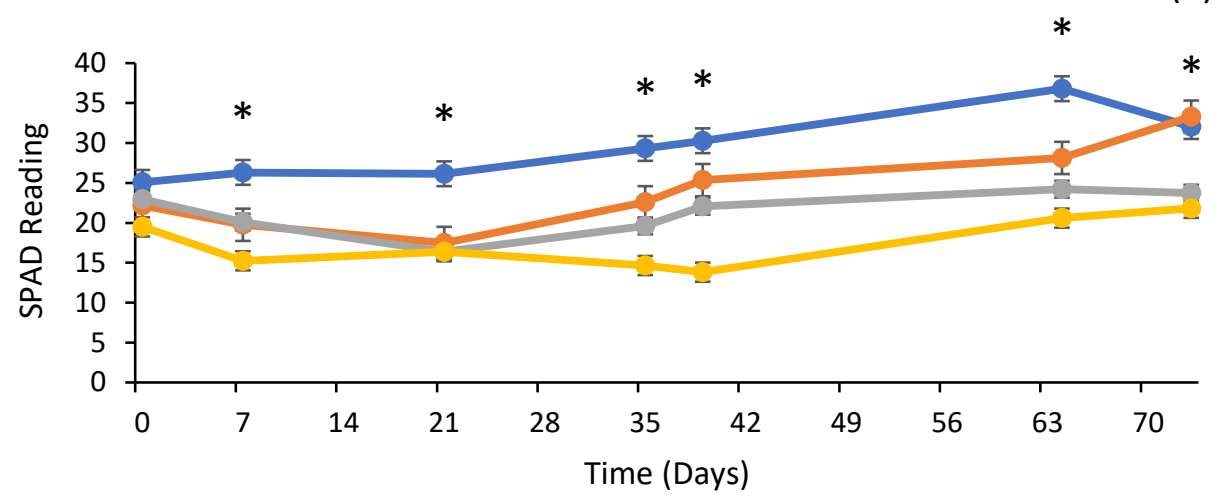

(f)

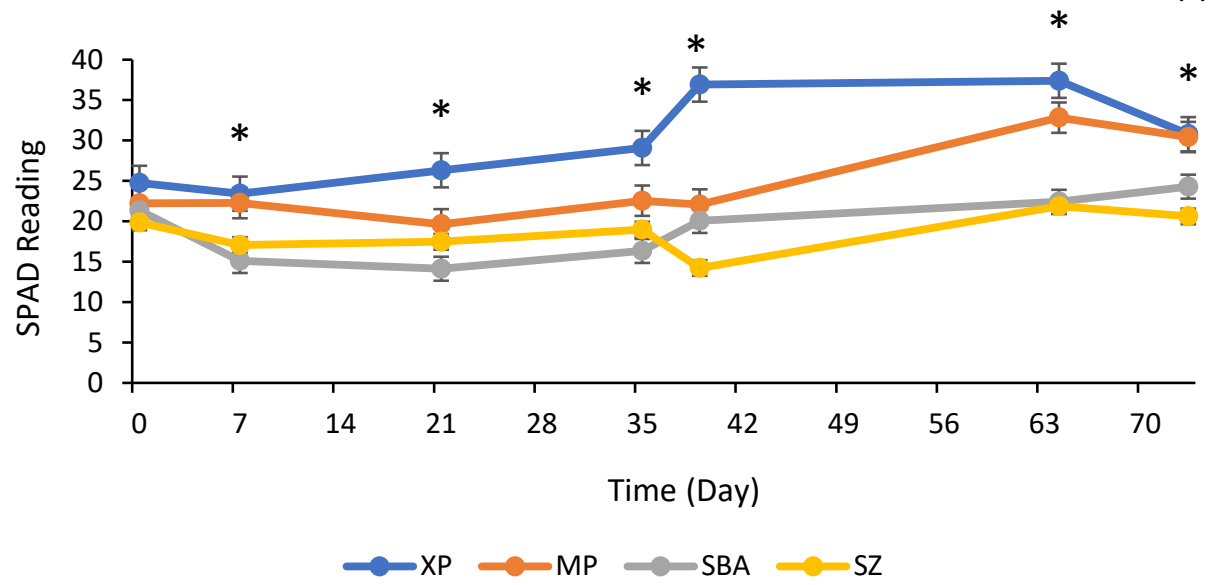

Figure 8: SPAD reading (indicative chlorophyll content) measures in potted trials for seasons 2019 and 2020/21.

XM- Xynisteri Mandria, XK- Xynisteri Kathikas, XP- Xynisteri Paphos, MP- Maratheftiko Paphos, SBCSauvignon Blanc Cyprus, SBA- Sauvignon Blanc Adelaide, SZ- Shiraz.

(a) Full irrigation 2019, (b) 50\% irrigation 2019, (c) 25\% irrigation 2019, (d) Full irrigation 2020/21, (e) $50 \%$ irrigation 2020/21, (f) 25\% irrigation 2020/21. Each data point are means of $n=10$ in 2019 and $n=7$ in 2020/21, Bars indicate the standard error. Means were separated by ANOVA using Tukey's test. * indicate significance at $p<0.05$ 
In 2019 XK and XM produced greater end of season root, trunk and shoot mass than SBC under all irrigation regimes and XK had greater root, trunk and shoot mass than XM with full irrigation (Table 6). All mass values were fresh weights taken one day after the final testing day. In 2020/21 XP had the highest root, shoot and leaf mass followed by MP, SBA and SZ. SZ had the lowest root, shoot and leaf mass at all irrigation levels except in the case of shoot mass with $25 \%$ irrigation where it was not statistically different to that of MP and SBA had the lowest mass (Table 6). When a 2-way ANOVA was applied to the data to assess for interactions between variety and irrigation, only the shoot length of Xynisteri when receiving full irrigation in 2019 was significantly affected.

In both seasons, root mass for Xynisteri was greater than the shoot and leaf mass (above ground biomass), while Maratheftiko, Shiraz and Sauvignon Blanc had similar root and above ground biomass ratios. However, in the cooler 2020/21 season root and shoot/leaf masses were higher than the warmer 2019 season. Jumrani et al., (2017) studying the effect of increased temperatures on soybean crops found that leaf weight and thickness decreased and the rate of photosynthesis and stomatal conductance also decreased with increased temperatures. Conversely, they observed that stomatal density increased significantly with increased temperatures. These changes were also seen in the cooler 2020/2021 season when compared to 2019, with the cooler season producing a decreased stomatal density (Table 6). Ferlito et al., (2020) studying Nerello Mascalese and Nero d'Avola on own roots and on drought tolerant rootstocks in a vineyard trial showed similar ratios with the drought tolerant rootstocks 140 Ruggeri and 1103 Paulsen having higher root masses than above ground masses when compared to corresponding own rooted vines. Yildirm et al., (2018) investigating Sultana grape vines grafted to three rootstocks, found that the drought tolerant rootstock $110 \mathrm{R}$ increased its root mass under drought and well-watered conditions at a greater rate than the rootstocks 5BB and $41 \mathrm{~B}$. They concluded that $110 \mathrm{R}$ was able to do this via drought dependent sugar and protein induction genes located in the roots. Gambetta et al., (2020) describe root volume as one of the most basic and enigmatic physiological traits of grapevines and that root volume has the potential to be used to determine the soil water reservoir that is available to the vine. Alsina et al., (2011) also found that drought-adapted rootstocks tend to have deeper roots. This may be one mechanism by which Xynisteri is also able to increase root mass in drought and wellwatered conditions. To a lesser extent Maratheftiko also had a larger root mass, but this was only statistically significant under $25 \%$ irrigation conditions. Prinsi et al., (2018) agree that roots may play a role in the grapevine's response to drought stress. They studied M4 rootstocks and concluded that carbon metabolism, mitochondrial function and other as yet unidentified mechanisms may be involved in the root mass, drought tolerance effect in grapevines. 
Chrysargyris et al., (2020) in their study comparing Xynisteri to Chardonnay found that non-irrigated Xynisteri had an increased level of the hormone abscisic acid (ABA). ABA is thought to play a role in the behaviour of stomata and reflects an increased capacity to react to water stress by altering stomatal conductance (Dayer et al., 2020, Prinsi et al., 2021). Sharp and LeNoble (2002), state that $A B A$ accumulation during water stress may often function to help maintain root as well as shoot growth, rather than to inhibit growth as is commonly believed. In recent times, the role of ABA and the expression of genes involved in its activity have been the subject of much research for possible drought resistance (Hopper et al. 2016, Wang et al., 2019, Liu et al., 2019b), however, no definitive mechanisms have been concluded to date. Li et al., (2020) state that root architecture is very important for $V$. vinifera and that ABA plays an important role in increased root growth, root hair growth and enhanced drought resistance.

The role of Xynisteri and Maratheftiko roots could be an important factor for vineyards in Australia were $80-95 \%$ of vineyards are planted without the use of rootstocks. Only one region (Riverland) has $45 \%$ of vineyards planted with vines using rootstocks (Vinehealth Australia 2021). Further research into the role of these root structures is therefore warranted.

Table 6: Fresh root, shoot and leaf mass (EL 38 Harvest) measures for potted trials for seasons 2019 and 2020/21.

\begin{tabular}{|c|c|c|c|c|c|c|c|c|c|}
\hline Mass (gm) & Root & & & Shoot & & & Leaf & & \\
\hline IR & Full & $50 \%$ & $25 \%$ & Full & $50 \%$ & $25 \%$ & Full & $50 \%$ & $25 \%$ \\
\hline \multicolumn{10}{|c|}{ Cyprus 2019} \\
\hline XM & $693 b$ & $582 a b$ & $387 a b$ & $264 b$ & $204 a$ & $112 b$ & $243 b$ & $184 a$ & $102 a b$ \\
\hline XK & $939 a$ & $643 a$ & $486 a$ & $377 a$ & $234 a$ & $180 a$ & $359 a$ & $208 a$ & $156 a$ \\
\hline SBC & $493 c$ & $352 b$ & $182 b$ & $109 c$ & $93 b$ & $63 c$ & $129 c$ & $93 b$ & $48 b$ \\
\hline $\operatorname{Pr}>\mathrm{F}$ & $<0.0001$ & 0.01 & $<0.0001$ & $<0.0001$ & 0.0001 & 0.0002 & $<0.0001$ & 0.0017 & 0.0001 \\
\hline \multicolumn{10}{|c|}{ Adelaide $20 / 21$} \\
\hline XP & $1233 \mathrm{a}$ & $1135 \mathrm{a}$ & 892 a & $458 a$ & $411 a$ & $342 a$ & $357 a$ & $291 a$ & $259 a$ \\
\hline MP & $620 \mathrm{~b}$ & $567 \mathrm{~b}$ & $539 b$ & $425 a b$ & $366 a b$ & 296ab & $252 a b$ & $240 a b$ & $201 a b$ \\
\hline SZ & $592 b$ & $445 \mathrm{~b}$ & $320 c$ & $299 b$ & $286 b$ & $238 a b$ & $215 b$ & $154 c$ & $137 b$ \\
\hline SBA & $610 \mathrm{~b}$ & $494 \mathrm{~b}$ & $443 b$ & $307 b$ & $274 b$ & $206 b$ & $236 b$ & $205 b c$ & $140 \mathrm{~b}$ \\
\hline $\mathrm{Pr}>\mathrm{F}$ & 0.0004 & $<0.0001$ & $<0.0001$ & 0.009 & 0.035 & 0.029 & 0.011 & 0.0003 & 0.001 \\
\hline
\end{tabular}

IR- Irrigation regime, Full= 8 litres per pot per week, 50\%= 4 litres per pot per week, 25\%= 2 litres per pot per week. XM- Xynisteri Mandria, XK-Xynisteri Kathikas, XP- Xynisteri Paphos, MP- Maratheftiko Paphos, SBC- Sauvignon Blanc Cyprus, SBA- Sauvignon Blanc Adelaide, SZ- Shiraz. Each data point are means of $n=10$ in 2019 and $n=7$ in 2020/21. Bars indicate the standard error. Means were separated by ANOVA using Tukey's test. *indicate significance at $p<0.05$, different letters next to the measures indicate significant differences. 


\subsection{Stomatal density}

In 2019, XK and XM had greater stomatal density than SBC. The Xynisteri stomatal density were the highest (similar to the findings of Copper et al., 2020), followed by MP, SZ and SBA (Table 6) in 2020/21. There was however some difference between the two seasons. As discussed previously, the 2019 testing period had a mean temperature of $24^{\circ} \mathrm{C}$ and the $2020 / 21$ growing season had a mean temperature of $21^{\circ} \mathrm{C}$. Rogiers et al., (2011) have reported that stomatal density is correlated to temperature, they report that the stomatal density can be as much as 1.4 times greater in warm temperatures when compared to cooler temperatures. This could help to explain the differences seen between 2019 and 2020/21 for Xynisteri with the warmer season producing higher stomatal densities. High stomatal density has been associated with drought tolerance, with Boso et al., (2011) suggesting that the high stomatal density of Albarinho may be responsible for its greater drought tolerance as it has an increased photosynthetic capacity. However, leaves for stomatal density were only collected at flowering, future studies to determine the impact of water status on these varieties could involve collecting leaves at different time points during an irrigation trial.

Table 7: Stomatal Density measures for potted trials for seasons 2019 and 2020/21.

\begin{tabular}{lll}
\hline Season & Variety & $\begin{array}{l}\text { Stomatal } \\
\text { Density }\end{array}$ \\
\hline 2019 & XCV & $238.6 \mathrm{a}$ \\
& XK & $227.5 \mathrm{a}$ \\
& $\mathrm{XM}$ & $233.2 \mathrm{a}$ \\
& $\mathrm{SBC}$ & $139.8 \mathrm{~b}$ \\
& $\mathrm{Pr}>\mathrm{F}$ & $<0.0001$ \\
\hline $2020 / 21$ & $\mathrm{XP}$ & $206.1 \mathrm{a}$ \\
& $\mathrm{MP}$ & $189.0 \mathrm{~b}$ \\
& $\mathrm{SZ}$ & $170.5 \mathrm{c}$ \\
& SBA & $151.4 \mathrm{~d}$ \\
& $\mathrm{Pr}>\mathrm{F}$ & $<0.0001$ \\
\hline
\end{tabular}

XCV- Xynisteri Cyprus Vineyard. XK, XM, XP- Xynisteri, MP- Maratheftiko, SBA, SBC- Sauvignon Blanc. Stomatal density- number of stomata per $\mathrm{mm}^{2}$. Each data point are means of $n=10$ in 2019 and $n=7$ in 2020/21. Bars indicate the standard error. Means were separated by ANOVA using Tukey's test. *indicate significance at $p<0.05$, different letters next to the measures indicate significant differences. 


\section{Conclusion}

This study, along with recent studies described above highlight the potential of the indigenous Cypriot varieties to tolerate reduced irrigation levels. Xynisteri and to a lesser extent Maratheftiko, were shown to have more vigorous growth than the commonly cultivated varieties of Sauvignon Blanc, Shiraz and Chardonnay in lower irrigation regimes. The study also demonstrated that while Xynisteri and Maratheftiko may be classified as stressed using conventional stem water potential and stomatal conductance parameters, they are able to continue to increase their biomass at greater rates than Shiraz and Sauvignon Blanc. In regions where irrigation is used to supplement rainfall, cultivation of these varieties could result in a reduction of the irrigation required and warrants further investigation with vineyard trials.

Overall, the biomass of Xynisteri above and below ground was far greater than all the other varieties investigated and under all irrigation regimes. Maratheftiko had greater leaf and shoot mass than Shiraz and Sauvignon Blanc for all irrigation regimes, but only had greater root mass under $25 \%$ irrigation. The role of the extensive root structure of Xynisteri is one area that requires further investigation. Although to date root biomass data for Xynisteri only exists for potted vines, field grown vines could better explain the role of the roots in drought tolerance in the future. To determine whether scion or root structure is more important to Xynisteri, trials with scion material grafted to differing rootstocks could be studied to assess the performance and assist in guiding future research. Future studies involving leaf anatomy and stomatal density of Maratheftiko could assist in determining the mechanism of its drought resilient properties.

A limitation to the potted trial was that no soil moisture sensors were utilised to determine the frequency of irrigation. Future vineyard trials could include soil moisture sensors to better guide the frequency and volume of irrigation under field conditions. Vineyard trials are currently being established in Australia, however this is a prolonged process due to the limited availability of scion material related to Australian government plant importation and quarantine laws. 


\section{Acknowledgements}

This project is supported through a University of Adelaide scholarship and funding from Wine Australia. Wine Australia is supported by Australian grape growers and winemakers with matched funds from the Australian Government. Authors gratefully acknowledge in Cyprus, Panikos and Filipos Kapnisis for allowing their vineyard to be studied and Stavros Zenonos for supplying space and water for the potted trial. Ektoras Tsiakkas, Christodoulos Karaolis and Savvas Savvides for assisting in taking measurements and vineyard advice. In Australia, Patrick O'Brien for assisting in taking measurements and Benjamin Pike for assistance in the vineyard including protecting vines from Kangaroos. 


\section{References}

Adamides, G. (2020). A review of climate-smart agriculture applications in Cyprus. Atmosphere, 11(9), 1-15. https://doi.org/10.3390/atmos11090898

Alatzas, A., Theocharis, S., Miliordos, D. E., Leontaridou, K., Kanellis, A. K., Kotseridis, Y., .and Koundouras, S. (2021). The effect of water deficit on two Greek Vitis vinifera L. cultivars: Physiology, grape composition and eene Expression during berry development. Plants, 10(9), 1-19. https://doi.org/10.3390/plants10091947

Allen, L. H., Zhang, L., Boote, K. J. and Hauser, B. A. (2018). Elevated temperature intensity, timing, and duration of exposure affect soybean internode elongation, mainstem node number, and pod number per plant. The Crop Journal, 6(2), 148-161. https://doi.org/10.1016/j.cj.2017.10.005

Alsina, M.M., Smart, D.R., Bauerle, T., de Herralde, F., Biel, C., Stockert, C., Negron, C. and Save, R. (2011). Seasonal changes of whole root system conductance by a drought-tolerant grape root system. Journal of Experimental Botany 62, 99-109. https://doi.org/10.1093/jxb/erq247

Azri, W., Cosette, P., Guillou, C., Rabhi, M., Nasr, Z. and Mliki, A. (2020). Physiological and proteomic responses to drought stress in leaves of two wild grapevines (Vitis sy/vestris): a comparative study. Plant Growth Regulation, 91(1), 37-52. https://doi.org/10.1007/s10725-020-00586-4

Bartlett, M. and Sinclair, G (2020). Temperature and evaporative demand drive variation in stomatal and hydraulic traits across grape cultivars. Journal of Experimental Botany, 72, 1995-2009. https://doi.org/10.1093/jxb/eraa577

Bauerle, T.L., Smart, D.R., Bauerle, W.L., Stockert, C. and Eissenstat, D.M. (2008), Root foraging in response to heterogeneous soil moisture in two grapevines that differ in potential growth rate. New Phytologist, 179, 857-866. https://doi.org/10.1111/j.1469-8137.2008.02489.x

Begg, J. E., and Turner, N. C. (1970). Water potential gradients in field tobacco. Plant Physiology, 46(2), 343-346. https://doi.org/10.1104/pp.46.2.343

Boso, S., Gago, P., Alonso-Villaverde, V., Santiago, J. L., Mendez, J., Pazos, I., \& Martínez, M. C. (2011). Variability at the electron microscopic level in leaves of members of the genus Vitis. Scientia Horticulturae, 128(3), 228-238. https://doi.org/10.1016/j.scienta.2011.01.022

Bureau of Meterology (2012), Record-breaking La Niña events. http://www.bom.gov.au/climate/enso/history/In-2010-12/three-phases-of-ENSO.shtml. Accessed $1^{\text {st }}$ March 2021. 
Bureau of Meterology (2021), Climate statistics for Australian locations.

http://www.bom.gov.au/climate/averages/tables/cw_023000_All.shtml Accessed 1st March 2021.

Cerovic, Z.G., Masdoumier, G., Ghozlen, N.B. and Latouche, G. (2012), A new optical leaf-clip meter for simultaneous non-destructive assessment of leaf chlorophyll and epidermal flavonoids.

Physiologia Plantarum, 146: 251-260. https://doi.org/10.1111/j.1399-3054.2012.01639.x

Chaves, M. M., Zarrouk, O., Francisco, R., Costa, J. M., Santos, T., Regalado, A. P., Rodrigues, M. L., \& Lopes, C. M. (2010). Grapevine under deficit irrigation: hints from physiological and molecular data. Annals of Botany, 105(5), 661-676. https://doi.org/10.1093/aob/mcq030

Chrysargyris, A., Xylia P., Antoniou, O. and Tzortzakis N. (2018a). Climate change due to heat and drought stress can alter the physiology of Maratheftiko local Cyprian grapevine variety. Journal of Water and Climate Change, 9(4), 715-727. https://doi.org/10.2166/wcc.2018.226

Chrysargyris, A., Xylia, P., Litskas, V., Mandoulaki, A., Antoniou, D., Boyias, T., Stavrinides, M., \& Tzortzakis, N. (2018b). Drought stress and soil management practices in grapevines in Cyprus under the threat of climate change. Journal of Water and Climate Change, 9(4), 703-714. https://doi.org/10.2166/wcc.2018.135

Chrysargyris, A., Xylia, P., Litskas, V., Stavrinides, M., Heyman, L., Demeestere, K., Höfte, M and Tzortzakis, N. (2020). Assessing the impact of drought stress and soil cultivation in Chardonnay and Xynisteri grape cultivars. Agronomy, 10(5), 670. https://doi.org/10.3390/agronomy10050670

Cifre, J., Bota, J., Escalona, J. M., Medrano, H., and Flexas, J. (2005). Physiological tools for irrigation scheduling in grapevine (Vitis vinifera L.): An open gate to improve water-use efficiency Agriculture, Ecosystems \& Environment, 106(2-3), 159-170. https://doi.org/10.1016/j.agee.2004.10.005

Collins, M. J., Fuentes, S. and Barlow E. W. R. (2010). Partial rootzone drying and deficit irrigation increase stomatal sensitivity to vapour pressure deficit in anisohydric grapevines. Functional Plant Biology, 37(2), 128-138. https://doi.org/10.1071/FP09175

Copper, A. W., Collins, C., Bastian, S., Johnson, T., Koundouras, S., Karaolis, C. and Savvides, S. (2020). Vine performance benchmarking of indigenous Cypriot grape varieties Xynisteri and Maratheftiko. OENO One, 54(4), 935-954. https://doi.org/10.20870/oeno-one.2020.54.4.3863 
Dayer, S., Scharwies, J. D., Ramesh, S. A., Sullivan, W., Doerflinger, F. C., Pagay, V. and Tyerman, S. D. (2020). Comparing hydraulics between two grapevine cultivars reveals differences in stomatal regulation under water stress and exogenous ABA applications. Frontiers in Plant Science, 11(705), 115. https://doi.org/10.3389/fpls.2020.00705

De Bei, R., Cozzolino, D., Sullivan, W., Cynkar, W., Fuentes, S., Dambergs, R. and Tyerman, S. (2011). Non-destructive measurement of grapevine water potential using near infrared spectroscopy. Australian Journal of Grape and Wine Research, 17(1), 62-71. https://doi.org/10.1111/j.17550238.2010.00117.x

Ferlito, F., G. Distefano, A. Gentile, M. Allegra, A. N. Lakso and E. Nicolosi (2020). Scion-rootstock interactions influence the growth and behaviour of the grapevine root system in a heavy clay soil. Australian Journal of Grape and Wine Research, 26(1), 68-78. https://doi.org/10.1111/ajgw.12415

Galat-Giorgi, E., Keller, M., Sadras, V., Roig, F. A. and Perez Peña, J. (2020). High temperature during the budswell phase of grapevines increases shoot water transport capacity. Agricultural and Forest Meteorology, 295, 108-173. https://doi.org/10.1016/j.agrformet.2020.108173

Gambetta, G.A., Herrera, J.C., Dayer, S., Feng, Q., Hochberg, U. and Castellarin, S.D. (2020). The physiology of drought stress in grapevine: Towards an integrative definition of drought tolerance. Journal of Experimental Botany, 71, 4658-4676. https://doi.org/10.1093/jxb/eraa245

García-Tejera, O., López-Bernal, A., Orgaz, F., Testi, L. and Villalobos, F. (2021). The pitfalls of water potential for irrigation scheduling. Agricultural Water Management, 243, 1-10.

https://doi.org/10.1016/j.agwat.2020.106522

Gerzon, E., Biton, I., Yaniv, Y., Zemach, H., Netzer, Y., Schwartz, A., Fait, A., and Ben-Ari, G. (2015). Grapevine anatomy as a possible determinant of isohydric or anisohydric behavior. American Journal of Enology and Viticulture, 66(3), 340-347. https://doi.org/10.5344/ajev.2015.14090

Girona, J., Mata, M., del Campo, J., Arbonés, A., Bartra, E., \& Marsal, J. (2006). The use of midday leaf water potential for scheduling deficit irrigation in vineyards. Irrigation Science, 24(2), 115-127. https://doi.org/10.1007/s00271-005-0015-7

Gonçalves, B., Falco, V., Moutinho-Pereira, J., Bacelar, E., Peixoto, F., and Correia, C. (2009). Effects of elevated $\mathrm{CO}_{2}$ on grapevine (Vitis vinifera $L$.): volatile composition, phenolic content, and in vitro antioxidant activity of red wine. Journal of Agricultural and Food Chemistry, 57(1), 265-273.

https://doi.org/10.1021/jf8020199 
Grigoriou, A., Tsaniklidis, G., Hagidimitriou, M. and Nikoloudakis, N. (2020). The Cypriot indigenous grapevine germplasm is a multi-clonal varietal mixture. Plants, 9(8), 1034-1048.

https://doi.org/10.3390/plants9081034

Hannah, L., Roehrdanz, P.R., Ikegami, M., Shepard, A.V., Shaw, M.R., Tabor, G., Zhi, L., Marquet P. A. and Hijmans R. J. (2013). Climate change, wine, and conservation. Proceedings of the National Academy of Sciences, 110(17), 6907-6912. https://doi.org/10.1073/pnas.1210127110

Heyman, L., Chrysargyris, A., Demeestere, K., Tzortzakis, N. and Höfte, M. (2021). Responses to drought stress modulate the susceptibility to Plasmopara viticola in Vitis vinifera self-rooted cuttings. Plants, 10(2), 1-25. https://doi.org/10.3390/plants10020273

Hilu, K. W., \& Randall, J. L. (1984). Convenient method for studying grass leaf epidermis. Taxon, 33(3), 413-415. https://doi.org/10.1002/j.1996-8175.1984.tb03896.x

Hochberg, U., Rockwell, FE., Holbrook, NM. and Cochard, H. (2018). Iso/anisohydry: a plantenvironment interaction rather than a simple hydraulic trait. Trends in Plant Science, 23, 112-120. https://doi.org/10.1016/j.tplants.2017.11.002

Hopper, D. W., Ghan, R., Schlauch, K. A., and Cramer, G. A. (2016). Transcriptomic network analyses of leaf dehydration responses identify highly connected $A B A$ and ethylene signalling hubs in three grapevine species differing in drought tolerance. BMC Plant Biology, 16(1), 1-20.

https://doi.org/10.1186/s12870-016-0804-6

Incrocci, L., Marzialetti, P., Incrocci, G., Di Vita, A., Balendonck, J., Bibbiani, C., Spagnol, S. and Pardossi, A. (2014). Substrate water status and evapotranspiration irrigation scheduling in heterogenous container nursery crops (2014), Agricultural Water Management, 131, 30-40, https://doi.org/10.1016/j.agwat.2013.09.004

Jarvis, C., Darbyshire, R., Goodwin, I., Barlow E.W.R. and Eckard, R. (2019). Advancement of winegrape maturity continuing for winegrowing regions in Australia with variable evidence of compression of the harvest period. Australian Journal of Grape and Wine Research, 25(1), 101-108. https://doi.org/10.1111/ajgw.12373

Jones, G. V., White, M. A., Cooper, O. R. and Storchmann, K. (2005). Climate change and global wine quality. Climatic Change, 73(3), 319-343. https://doi.org/10.1007/s10584-005-4704-2 
Jones, G. V., Duff, A. A., Hall, A. and Myers, J. W. (2010). Spatial analysis of climate in winegrape growing regions in the Western United States. American Journal of Enology and Viticulture, 61(3), 313-326. https://www.ajevonline.org/content/61/3/313.article-info

Jumrani, K., Bhatia V. S., and Pandey, G. P. (2017). Impact of elevated temperatures on specific leaf weight, stomatal density, photosynthesis and chlorophyll fluorescence in soybean. Photosynthesis Research, 131(3), 333-350. https://doi.org/10.1007/s11120-016-0326-y

Keller, M. (2010). Managing grapevines to optimise fruit development in a challenging environment: a climate change primer for viticulturists. Australian Journal of Grape and Wine Research, 16(1), 5669. https://doi.org/10.1111/j.1755-0238.2009.00077.x

Keller, M. and Tarara, J. M. (2010). Warm spring temperatures induce persistent season-long changes in shoot development in grapevines. Annals of Botany, 106(1), 131-141. https://doi.org/10.1093/aob/mcq091

Krieger, M., Lohmann, G. and Laepple, T. (2011). Seasonal climate impacts on the grape harvest date in Burgundy (France). Climate of the Past, 7(2), 425-435. https://doi.org/10.5194/cp-7-425-2011

Koufos, G., Mavromatis, T., Koundouras, S. and G. Jones, G. (2020). Adaptive capacity of winegrape varieties cultivated in Greece to climate change: current trends and future projections. OENO One, 54, 1201-1219. https://doi.org/10.20870/oeno-one.2020.54.4.3129

Levin, A. D., Williams, L. E and Matthews, M. A. (2020). A continuum of stomatal responses to water deficits among 17 wine grape cultivars. Functional Plant Biology, 47(1), 11-25.

https://doi.org/10.1071/FP19073

Li, H., Gao, Z., Chen, Q., Li, M., Luo, J., Wang, L., Hu, M. S., Zahid, L., Wang, L., Zhao, S., Song, W., Xu, C., Zhang, C., Ma, C. and Wang, S. (2020). Grapevine ABA receptor VvPYL1 regulates root hair development in transgenic Arabidopsis. Plant Physiology and Biochemistry, 149, 190-200. https://doi.org/10.1016/j.plaphy.2020.02.008

Liles, C. and Verdon-Kidd, D. C. (2020). Refining the growing season temperature parameter for use in winegrape suitability analysis. Australian Journal of Grape and Wine Research, 26(3), 1-15. https://doi.org/10.1111/ajgw.12447

Ling, Q., Huang, W. and Jarvis, P. (2011). Use of a SPAD-502 meter to measure leaf chlorophyll concentration in Arabidopsis thaliana. Photosynthesis Research 107, 209-214.

https://doi.org/10.1007/s11120-010-9606-0 
Litskas, V. D., Tzortzakis, N. and Stavrinides, M. C. (2020). Determining the carbon footprint and emission hotspots for the wine produced in Cyprus. Atmosphere, 11(5), 463, 1-14.

https://doi.org/10.3390/atmos11050463

Liu, C., Liu, Y., Lu, Y., Liao, Y., Nie, J., Yuan, X. and Chen, F. (2019a). Use of a leaf chlorophyll content index to improve the prediction of above-ground biomass and productivity. PeerJ-Life and Environment, 6, 1-15. https://doi.org/10.7717/peerj.6240

Liu, J., Zhao, F. L., Guo, Y., Fan, X. C., Wang Y. J. and Wen, Y. Q. (2019b). The ABA receptor-like gene VYPYL9 from drought-resistance wild grapevine confers drought tolerance and ABA hypersensitivity in Arabidopsis. Plant Cell, Tissue and Organ Culture, 138(3), 543-558.

https://doi.org/10.1007/s11240-019-01650-2

Meron, M., Grimes, D. W., Phene, C. J. and Davis, K. R. (1987). Pressure chamber procedures for leaf water potential measurements of cotton. Irrigation Science, 8(3), 215-222.

https://doi.org/10.1007/BF00259382

Metay, A., Magnier, J., Guilpart, N. and Christophe, A. (2014). Nitrogen supply controls vegetative growth, biomass and nitrogen allocation for grapevine (cv. Shiraz) grown in pots. Functional Plant Biology, 42(1), 105-114. https://doi.org/10.1071/FP14062

Nambuthiri, S., Hagen, E., Fulcher, A., \& Geneve, R. (2017). Evaluating a physiological-based, ondemand irrigation system for container-grown woody plants with different water requirements, Horticultural Science, 52(2), 251-257. https://doi.org/10.21273/HORTSCI10603-16

Phogat, V., Cox, J. W., Mallants, D., Petrie, P. R., Oliver, D. P., \& Pitt, T. R. (2020). Historical and future trends in evapotranspiration components and irrigation requirement of winegrapes. Australian Journal of Grape and Wine Research, 26(4), 312-324. https://doi.org/10.1111/ajgw.12446

Prinsi, B., Negri, A. S., Failla, O., Scienza, A. and Espen, L. (2018). Root proteomic and metabolic analyses reveal specific responses to drought stress in differently tolerant grapevine rootstocks. $B M C$ Plant Biology, 18(1), 1-28. https://doi.org/10.1186/s12870-018-1343-0

Prinsi, B., Simeoni, F., Galbiati, M., Meggio, F., Tonelli, C., Scienza, A. and Espen, L. (2021). Grapevine rootstocks differently affect physiological and molecular responses of the scion under water deficit condition. Agronomy, 11(2), 1-15. https://doi.org/10.3390/agronomy11020289 
Rogiers, S. Y., Hardie, W. J., and Smith, J. P. (2011). Stomatal density of grapevine leaves (Vitis vinifera $L$.$) responds to soil temperature and atmospheric carbon dioxide. Australian Journal of$ Grape and Wine Research, 17(2), 147-152. https://doi.org/10.1111/j.1755-0238.2011.00124.x

Remenyi, T.A., Rollins, D.A., Love, P.T., Earl, N.O., Bindoff, N.L. and Harris, R.M.B. (2019). Australia's wine future. A Climate Atlas, University of Tasmania, Hobart, Tasmania. http://ecite.utas.edu.au/137759

Rhie, Y. H. and Kim, J. (2017). Changes in physical properties of various coir dust and perlite mixes and their capacitance sensor volumetric water content calibrations. Horticulture Science, 52(1), 162. https://doi.org/10.21273/HORTSCI11362-16

Sharp, R. E. and LeNoble, M. E. (2002). ABA, ethylene and the control of shoot and root growth under water stress. Journal of Experimental Botany, 53(366), 33-37. https://doi.org/10.1093/jexbot/53.366.33

Schultz, H. R. (2003). Differences in hydraulic architecture account for near-isohydric and anisohydric behaviour of two field-grown Vitis vinifera L. cultivars during drought. Plant, Cell \& Environment, 26(8), 1393-1405. https://doi.org/10.1046/j.1365-3040.2003.01064.x

Schultz, H. R., and Jones, G. V. (2010). Climate induced historic and future changes in viticulture. Journal of Wine Research, 21(23), 137-145. https://doi.org/10.1080/09571264.2010.530098

Smart, R. E. (1985). Principles of grapevine canopy microclimate manipulation with implications for yield and quality. A review. American Journal of Enology and Viticulture, 36(3), 230.

Steele, M. R., Gitelson, A. A., \& Rundquist, D. C. (2008). A comparison of two techniques for nondestructive measurement of chlorophyll content in grapevine leaves. Agronomy Journal, 100(3), 779-782. https://doi.org/10.2134/agronj2007.0254N

Theodorou, N., Nikolaou, N., Zioziou, E., Kyraleou, M., Kallithraka, S., Kotseridis, Y., and Koundouras, S. (2019). Anthocyanin content and composition in four red winegrape cultivars (Vitis vinifera L.) under variable irrigation. OENO One, 53(1), 39-51. https://doi.org/10.20870/oenoone.2019.53.1.2366

Trad, M., Renard, C. M., and Harbi, M. (2021). Key descriptors for sugars and acids to evaluate Vitis sylvestris grapevines. Journal of Horticultral Science and Forestry, 3(103) 1-12. 
Tzortzakis, N., Chrysargyris, A. and Aziz, A. (2020). Adaptive response of a native Mediterranean grapevine cultivar upon short-term exposure to drought and heat stress in the context of climate change. Agronomy, 10(2), 249. https://doi.org/10.3390/agronomy10020249

van Leeuwen, C., Destrac-Irvine, A., Dubernet, M., Duchêne, E., Gowdy, M., Marguerit, E., Pieri, P., Parker, A., de Rességuier, L. and Ollat, N. (2019). An update on the impact of climate change in viticulture and potential adaptations. Agronomy, 9(9), 1-20.

https://doi.org/10.3390/agronomy9090514

van Leeuwen, C., Schultz, H. R., Garcia de Cortazar-Atauri, I., Duchêne, E., Ollat, B., Pieri, P. Bois, B., Goutouly, J.-P., Quénol, H., Touzard, J. M., Malheiro, A. C., Bavaresco, L. and Delrot, S. (2013). Why climate change will not dramatically decrease viticultural suitability in main wine-producing areas by 2050. Proceedings of the National Academy of Sciences, 110(33), E3051-E3052.

https://doi.org/10.1073/pnas.1307927110

Vink, S. N., Chrysargyris, A., Tzortzakis, N. and Salles J. F. (2021). Bacterial community dynamics varies with soil management and irrigation practices in grapevines (Vitis vinifera L.). Applied Soil Ecology, 158, 103-107. https://doi.org/10.1016/j.apsoil.2020.103807

Vinehealth Australia (2021), Government of South Australia. Accessed 14 ${ }^{\text {th }}$ December 2021. https://vinehealth.com.au/2021/11/rootstock-deep-dive/

Villalobos-González, L., Muñoz-Araya, M., Franck, N. and Pastenes, C. (2019). Controversies in midday water potential regulation and stomatal behavior might result from the environment, genotype, and/or rootstock: evidence from Carménère and Syrah grapevine varieties. Frontiers in Plant Science, 10, 1-15. https://doi.org/10.3389/fpls.2019.01522

Wang, Y. T., Chen, Z. Y., Jiang, Y., Duan, B. B. and Xi, Z. M. (2019). Involvement of ABA and antioxidant system in brassinosteroid-induced water stress tolerance of grapevine (Vitis vinifera $L$.$) .$ Scientia Horticulturae, 256, 108-596. https://doi.org/10.1016/j.scienta.2019.108596

Webb, L. B. (2011). Adaptation of the Australian wine industry to climate change - opportunities and vulnerabilities. University of Melbourne and CSIRO, Australia https://www.wineaustralia.com/research/projects/adaptation-of-the-australian-wine-indust Accessed 1st July 2021.

Webb, L. B., Watterson, I., Bhend, J., Whetton, P. H. and Barlow, E. W. R. (2013). Global climate analogues for winegrowing regions in future periods: projections of temperature and precipitation. Australian Journal of Grape and Wine Research, 19(3), 331-341. https://doi.org/10.1111/ajgw.12045 
Yıldırım, K., Yağcı, A., Sucu, S. and Tunç, S. (2018). Responses of grapevine rootstocks to drought through altered root system architecture and root transcriptomic regulations. Plant Physiology and Biochemistry, 127, 256-268. https://doi.org/10.1016/j.plaphy.2018.03.034 